\title{
Remuneration systems used in the fishing sector and their consequences on crew wages and labor rent creation
}

\author{
Jordi Guillen ${ }^{1,2^{*}}$, Jean Boncoeur ${ }^{3 \dagger}$, Natacha Carvalho ${ }^{1 \dagger}$, Katia Frangoudes $^{3 \dagger}$, Olivier Guyader $^{4 \dagger}$, Claire Macher $^{4 \dagger}$ \\ and Francesc Maynou ${ }^{2+}$
}

* Correspondence:

jordi.guillen@jrc.ec.europa.eu

${ }^{\dagger}$ Equal contributors

${ }^{1}$ European Commission, Joint Research Centre, Directorate D Sustainable Resources, Unit D.02 Water and Marine Resources, Via E. Fermi 2749, 21027 Ispra, Italy ${ }^{2}$ Institut de Ciències del Mar - CSIC, Psg. Marítim de la Barceloneta 37-49, 08003 Barcelona, Spain Full list of author information is available at the end of the article

\begin{abstract}
In most fisheries worldwide, crew are paid through different shared remuneration systems rather than a fixed wage. In shared remuneration systems, wages can significantly increase when the economic performance of vessels improve, and consequently provide incentives to workers. However, in recent years, mainly due to high overexploitation levels that lead to reduced productivity and consequently lower salaries shared remuneration systems have lost their attractiveness. Different remuneration systems applied in fisheries world-wide are described and analyzed comparatively. Results explain how crew wages and rent distribution outcomes vary between the different remuneration systems depending on the state of exploitation of the resource.
\end{abstract}

\section{Introduction}

The fishing sector is an important economic sector, source of wealth, food supply and nutrition security (McClanahan et al. 2013; Hall et al. 2013). In 2012, capture fisheries produced 91.3 million tons of fish, and 66.6 million tons of fish were obtained from aquaculture (FAO 2014a). Of these 158 million tons, 136.2 million tons were used for human consumption, which is equivalent to an average consumption of $19.2 \mathrm{~kg}$ of fish per capita. Around 58.3 million people were engaged in the primary sector of capture fisheries and aquaculture in 2012 (FAO 2014a). Of these, about 40 million were engaged in capture fisheries.

Many economic activities worldwide remunerate their workers using time based remunerations: fixed wages (monthly salaries) or hourly or daily rates (Schloss 1898; Kessler 2009). Additionally, in some remuneration systems workers' salary is complemented with incentives, by relating the wage to the worker's output (i.e., piece rate, task wage), using a combination of time and output remunerations or bonus and commission systems (Schloss 1898; Lazear 1986; Kessler 2009). Many of these remuneration systems were developed following the needs of the industrial sector (Schloss 1898).

In the agricultural and fishing sectors incentives play a more important role. In the agriculture sector sharecropping contracts are almost universal throughout the world, where the tenant pays a specific proportion of the produce or of the gross sales to the landlord (Johnson 1950; Stiglitz 1974; Reid 1976; Newbery 1977; Allen 1985).

(c) The Author(s). 2017 Open Access This article is distributed under the terms of the Creative Commons Attribution 4.0 International License (http://creativecommons.org/licenses/by/4.0/), which permits unrestricted use, distribution, and reproduction in any medium, provided you give appropriate credit to the original author(s) and the source, provide a link to the Creative Commons license, and indicate if changes were made. 
In the fishing sector, remuneration systems based on productivity prevail, consequently providing incentives for the crew to increase production. Crew are usually remunerated through shared remuneration systems (also known as lay systems) rather than fixed wages (i.e., Zoeteweij 1956; Acheson 1981; Anderson 1982; Platteau and Nugent 1992; Matthiasson 1997; McConnell and Price 2006). In these remuneration systems, crew members are paid with a share of the revenues (i.e., value of landings) or a share of the revenues minus costs.

This practice of paying the crew with shared remuneration systems is applied to both small scale and industrial fisheries, as well as in developed and developing countries. Indeed, it is extensive to fisheries worldwide as can be seen from Table 1:

Table 1 Existing references on the use of shared remuneration systems

\begin{tabular}{|c|c|c|}
\hline Continent & Country & Reference \\
\hline \multirow[t]{5}{*}{ Africa } & Ghana & Christensen 1977 \\
\hline & Morocco & Malouli Idrissi et al. 2003 \\
\hline & & Kamili 2006 \\
\hline & Senegal & Tietze et al. 2001 \\
\hline & Tunisia & Azabou et al. 1989 \\
\hline \multirow[t]{10}{*}{ America } & Brazil & Giasson 1981 \\
\hline & Canada & Breton 1973 \\
\hline & Chile & Salazar 2015 \\
\hline & Ecuador & Middleton 1977 \\
\hline & Barbados & Tietze et al. 2001 \\
\hline & French Guyana & Béné 1996 \\
\hline & Guadeloupe & Guyader et al. 2013 \\
\hline & Mexico & McGoodwin 1976 \\
\hline & United States & McConnell and Price 2006 \\
\hline & & Abbott et al. 2010 \\
\hline \multirow[t]{7}{*}{ Asia } & India & Bavinck 2001 \\
\hline & Republic of Korea & Tietze et al. 2001 \\
\hline & Philippines & Smith et al. 1983 \\
\hline & Sri Lanka & Alexander 1977 \\
\hline & Thailand & ILO 2013 \\
\hline & Turkey & Ünal 2002 \\
\hline & Vietnam & Thuy et al. 2013 \\
\hline \multirow[t]{9}{*}{ Europe } & France & Guillen et al. 2015 \\
\hline & Iceland & Matthiasson 1997 \\
\hline & Italy & Colloca et al. 2003 \\
\hline & Spain & Lleonart, et al. 1999, 2003 \\
\hline & & Maynou et al. 2006 \\
\hline & & Prellezo and Iriondo 2016 \\
\hline & Sweden & Lofgren 1972 \\
\hline & United Kingdom & Hatcher 2010 \\
\hline & & McCall Howard 2012 \\
\hline \multirow[t]{2}{*}{ Oceania } & Australia & George and New 2013 \\
\hline & & Skirtun, Stephan and Mazur 2014 \\
\hline
\end{tabular}


Shared remuneration systems have traditionally been used in fisheries because they improve productivity (Weitzman and Kruse 1990). This is because shared remuneration systems share risks (costs) and rents (profits) between the crew and the vessel owner (Stiglitz 1974; Sutinen 1979; Acheson 1981; Plourde and Smith 1989; McGoodwin 1991), and provide incentives based on outputs in situations where monitoring of worker's effort is unobservable or costly (Stiglitz 1974; Eisenhardt 1989; McConnell and Price 2006; Vestergaard 2010).

Moreover, in addition to the principal-agent problem where captains may have incentives to apply a different fishing effort depending if they are the owners of the vessels or not, in order to maximize their personal income (Eisenhardt 1989; Vestergaard 2010); the use of different remuneration systems leads to different fishing efforts in order to achieve the management objectives independently of the presence of the vessel owner (Guillen et al. 2015).

Shared remuneration systems allow the crew to obtain higher wages by capturing part of the fisheries rent when the economic performance of the vessel improves (Griffin et al. 1976), in part due to the crew work. Fisheries rent is a "surplus" from the exploitation of fisheries resources. It is estimated as the difference between total revenues obtained from the fishery and the total costs (estimated at their opportunity costs) of employing the various factors of production (including charges for replacement of assets) that together make up the firms participating in the fishery (Guillen et al. 2015).

Therefore, fisheries rent is divided between owners (capital) rent and labor rent. Being the owners rent the extra current profits (above the opportunity cost of capital); while labor rent is estimated as the difference between current wages and the opportunity cost of labor. This can act as an incentive to improve the attractiveness of the fishing sector on the labor market because it is an activity where the strenuousness of work onboard limits the labor supply, as well as an incentive to increase the labor time and effort.

However, there are important variations in the shared remuneration systems used worldwide. Main differences between shared remuneration systems depend on which costs are deducted from the crew part. Moreover, when crew are paid through shared remuneration systems, the sharing within crew members is often not homogeneous, highlighting differences in marginal productivity and payment of labor quasi rents.

The Sunken billions report (Willmann et al. 2008) estimates labor costs in global fisheries to be between 30 and $50 \%$ of total costs. Labor costs represent on average about $35 \%$ of the total EU fishing fleets costs (STECF 2012). While, Jin et al. (2002) estimate that labour costs represent 30 to $60 \%$ of total costs (including fixed costs) for the New England groundfish fleet. Labor costs constitute an important part of the fishing costs and consequently have a significant impact on the economic performance and strategies of the different fleets. It is, therefore, important to understand how labor costs rise and labor rent is created.

Fisheries management measures have a direct impact on the creation of fisheries (or resource) rent (see, for instance, Guillen et al. 2013); while the remuneration systems have a direct impact on the fisheries rent distribution between the vessel owner and the crew. In shared remuneration systems, therefore, fisheries management measures have also an impact on labor costs and crew wages. 
Most countries manage their fisheries to achieve a combination of biologic, economic, social, and political objectives (Mardle et al. 2002; Hilborn 2007; Dichmont et al. 2010). However, management objectives are often conflicting and it is not possible to achieve all of them at the same time.

- As a biological objective, Maximum Sustainable Yield (MSY) is interpreted as the maximum long term average catch that can be achieved under prevailing conditions, including both the state of the ecosystem and size selectivity of the fishery (ICES 2010). Thus, the target of fisheries operating at MSY meets both biological sustainability and production maximization objectives (Beverton and Holt 1957; Hilborn and Stokes 2010). Hence, under this management objective, often revenues are maximized ${ }^{1}$ but not profits. However, in this study, it is assumed that price is related to the fish biomass at sea, following Willmann et al. (2008). Consequently, the fishing effort level that maximizes production (catches) is not the same one that maximizes revenues.

- As an economic objective, Maximum Economic Yield (MEY) can be defined as the sustainable catch that maximizes the difference between total revenues and total costs of fishing (Huntsman 1951; Gordon 1954; Kompas 2005). So, the MEY should correspond to the catch of an optimally managed fishery aiming at maximizing the rents extracted from the fishery. Therefore, differentiating between maximizing rents (profits and labor rents) which strictly corresponds to MEY, and maximizing only profits.

- As a social objective, the maximum employment target can be defined, following Pilling et al. (2008), as the maximum effort, and consequently employment, in a nonloss making fishery. So this management objective corresponds to the bio-economic equilibrium or open access point. In an open access fishery, the bio-economic equilibrium is given at an effort level where profit is zero and total fishing cost is equal to total revenue (Hannesson 1993).

The objective of this study is to explore the effects and see the divergences of different remuneration systems by estimating the evolution of crew wages and the distribution of rents between labor and capital (the vessel owner) at several fisheries management targets. Here, the management objectives analyzed are maximum production (MSY), maximum revenues, maximum rents (MEY), maximum profits and maximum employment or bio-economic equilibrium compared to the status quo (when current fishing effort remains constant) for the global marine fisheries.

\section{Methodology}

\section{Compilation of fisheries remuneration systems used world-wide}

There are important variations in the shared remuneration systems used worldwide. One of the main variations in shared remuneration systems is on the extent to which crew participates in paying the costs (Zoeteweij 1956). From a literature review, we identified 4 remuneration systems commonly used in fisheries: (i) fixed remuneration systems (case 1), (ii) shared remuneration system: proportional to catch or revenues (case 2), (iii) shared remuneration system: proportional to 
revenues minus operational costs (case 3) and (iv) shared remuneration system: proportional to profits (case 4).

However, sometimes fishermen's remuneration include items of several of these groups; for example: (i) in the small-scale purse seiners in Vietnam crew can be paid with a fixed wage (case 1) and a small bonus based on a share of the revenues (case 2) (Thuy et al. 2013); (ii) in the trawler fleet in Mediterranean Spain the main remuneration system is a share of the revenues minus operational costs (case 3), but crew also receive a small part of the landings (morralla, composed of species with low value ${ }^{2}$ ) (case 2) (Lleonart et al. 1999, 2003; Alemany and Álvarez 2003; Maynou et al. 2006; Samy-Kamal et al. 2014).

It is also possible that in a fishery different remuneration systems coexist, as shown in (i) Ünal (2002) where $67 \%$ of the trawl vessels in Turkey used a fixed wage (case 1) and 33\% a share system (case 3); (ii) Thuy et al. (2013) for the small-scale purse seiners in Vietnam that used a fixed wage with a small bonus based on a share of the revenues (cases 1 and 2) or a share remuneration of the revenues minus the variable costs (case 3); and (iii) fishers in Thailand receive a remuneration proportional to the sale of the $\mathrm{catch}^{3}$ in $41.3 \%$ of the cases, a fix wage plus a proportion of the catch (38.9\%), or a fix wage only (10.4\%) (ILO 2013). Moreover, in recent years, together with the difficulties for vessel owners to find crew in certain fisheries, crew is asking to be paid with fixed wages rather than shared remuneration systems.

It should also be noted that due to the little attention paid to the remuneration systems used in fisheries, these systems are often not specified in detail and their functioning oversimplified. For example, this oversimplification can lead to the literature stating that fisheries operate through shared remuneration systems proportional to the catch (case 2); when in fact the same fisheries are actually remunerated through shared remuneration systems proportional to the revenues minus the operational costs (case 3).

\section{Case 1: fixed remuneration system}

In a fixed remuneration system, crew are paid with a constant (fixed) wage, either daily, monthly or at another time-scale. Examples of this system include:

- The US Chesapeake Bay blue crab fishery uses a pure (fix) wage system in approximately $40 \%$ of the trips (McConnell and Price 2006);

- The US factory trawlers in the Bering Sea harvesting and processing groundfish remunerate the processing crew and engineers primarily via a (fix) daily wage (McConnell and Price 2006);

- $67 \%$ of the trawl vessels in Turkey (Ünal 2002);

- Some small-scale purse seiners in Vietnam remunerate the crew with a daily fixed wage of about 30 to 40 thousand Vietnamese Dong (case 1), complemented with $10 \%$ of the total revenues shared between the crew (case 2) (Thuy et al. 2013);

- The industrial fleet of Saint-Malo (France) remunerates crew with a fixed wage to guarantee the crew a minimum wage and a shared wage to act as an incentive.

\section{Case 2: shared remuneration system (proportional to catch or revenues)}

Zoeteweij (1956) points out that the income of fishermen is more often determined by the value of the catch rather than its size. Indeed, in those fisheries where no costs are 
deducted from the revenues before compensating the crew, the remuneration is often proportional to the revenues and not the catch. A remuneration proportional to the catches only matches with remuneration proportional to the revenues when there is only one species or several species with the same price. The distinction between share of catches and revenues is relevant because it is possible to catch different species or sizes with different prices at the same time (i.e. a large amount of low valued species and just few of high valued ones), so both outcomes would be different. Some examples of fisheries using shared remuneration systems proportional to revenues are:

- The US factory trawlers in the Bering Sea harvesting and processing groundfish remunerate their harvesting crews with a share of the revenues (typically 30-35\% in aggregate) (McConnell and Price 2006).

- In the French Guyana shrimp fishery remuneration is compounded by a share of the catch, and a bonus that provides incentives to the crew to target large shrimps during periods of high resource levels and smaller shrimps during months of lower catch levels (Béné 1996).

- Icelandic vessels remunerate their crew with a share of the revenues without considering the costs (Matthiasson 1997).

- In the artisanal fishery of Cilento (Italy), crew members receive about $50 \%$ of the revenues, and any fish that have not been sold because of damage or no commercial value (Colloca et al. 2003).

- In the Basque (North West of Spain) traditional purse seiner-live bait fleet, which fish small pelagics using purse seiners and big pelagics (tuna) using live bait with hooks, the crew receive $50 \%$ of the net value of landings (once the landing fee is deduced) (Astorkiza et al. 1998; Prellezo and Iriondo 2016).

\section{Case 3: shared remuneration system (proportional to revenues minus operational costs)}

The share rate and the operating costs (or variable costs) that are deducted from the value of landings before sharing can vary between fishing fleets, fisheries, countries, and even vessels. For example, in the Netherlands, in general, fuel cost, which is the main operating cost, is deducted from the value of landings (Bartelings et al. 2015); while in France and Spain usually fuel, ice, food, and bait costs are deduced (Lleonart et al. 1999, 2003; Maynou et al. 2006; Macher et al. 2008). Some examples of fisheries using shared remuneration systems proportional to revenues minus operational costs are:

- The remuneration system in Moroccan fisheries is mainly based on shared remuneration for artisanal fishing and coastal fisheries (i.e., seiners, trawlers, longliners); while the high seas fleet remunerates their crew mainly with monthly wages, but includes a supplement based on a small percentage of the catch (Kamili, personal communication). The purse-seine fishery remunerates their crew with a $60 \%$ share of the revenues minus operational costs, but crew also receive a $1-2 \%$ of the landings (called fakira) (Kamili 2006); while in the artisanal fleet in the Nador Lagoon the share rate is 50\% (Malouli Idrissi et al. 2003);

- In Tunisia crew are paid with a share of the revenues once operational costs are subtracted (Azabou et al. 1989); 
- Almost all commercial fisheries in the US remunerate their crew with a share of the revenues minus certain costs (McConnell and Price 2006). Indeed, crew in the Bering Sea/Aleutian Island crab fisheries are remunerated with a share of the revenues minus certain costs. The costs items subtracted to the revenues, as well as the share rate (on average is around 40\%, but varies between 30 and 50\%) depends on the vessel (Abbott et al. 2010);

- $33 \%$ of the trawl vessels in Turkey remunerate their crew with this remuneration system (Ünal 2002);

- Some small-scale purse seiners in Vietnam use a share remuneration of the revenues minus the variable costs (Thuy et al. 2013);

- The trawl fisheries in the Spanish Mediterranean remunerate their crew with a share (often 50\%) of the revenues minus operational costs (case 3), but crew also receive a small part of the landings (morralla, composed of low valued species) (case 2) (Lleonart et al. 1999, 2003; Maynou et al. 2006);

- In France, the most common remuneration system is based on a share of the revenue minus the operational costs (landings costs, fuel costs, bait costs, food costs and ice costs), as modeled in Macher et al. (2008) for the nephrops fishery in the Bay of Biscay.

\section{Case 4: shared remuneration system (proportional to profits)}

In this remuneration system, crew members are paid with a proportion of the profits. In this case, all costs are deduced to the revenues before sharing it with the crew. This is mostly a hypothetical model that allows us to cover all possible ranges, as it seldom occurs in reality.

- It could be the case in very artisanal fisheries where there is scarcity of labor and the possibility of obtaining production means cheaply (low capital investment), as in an artisanal fleet in the Canary Islands (Spain) using $5 \mathrm{~m}$ long vessels when there is no share to remunerate capital (Pascual Fernandez 1999).

- Theoretically, it could also be the case in cooperatives where all fishermen are owners of the production means.

- Theoretically, this could also be the case on small boats when there is only one crew, who is also the owner of the vessel. In this case, the distinction between remuneration of labor and remuneration of the invested capital is not systematic (Boncoeur et al. 2000). ${ }^{4}$

\section{The bioeconomic model}

In order to explore the sensitivity of existing remuneration systems to different management targets and so different economic performances, we analyzed the global marine fisheries as represented in the Sunken Billions (Willmann et al. 2008), using a Gordon-Schaefer bio-economic model (Gordon 1953, 1954; Schaefer 1954, 1957).

Basic population dynamics are used to illustrate how fisheries work and provide the basis for understanding issues such as optimal harvesting rates, predation and habitat destruction. Population dynamics describe the ways in which a given population grows and shrinks over time, due to by birth, death, and migration. Fish stock growth 
(change) depends on recruitment, natural mortality, individual growth and harvesting. This may be summarized as follows:

Stock growth $=$ Recruitment + Individual growth - Natural mortality - Harvest.

A typical model of population growth is based on the logistic equation, where the rate of growth is proportional to both the existing population and the amount of available resources, all else being equal (Verhulst 1838; Clark 1976). So, the growth of a fish stock can be expressed in the continuous version of the logistic model described by the differential equation used in the Verhulst/Pearl surplus production model (Schaefer 1970):

$$
F\left(x_{t}\right)=r X_{t}\left(1-\frac{X_{t}}{K}\right)
$$

Where $X_{t}$ is the biomass level of the stock or stock size (weight of the stock) at time $t, F\left(X_{t}\right)$ represents the change in stock per unit of time $d X(t) / d t$, the constant $r$ is the Malthusian parameter that refers to the rate of maximum population growth and $K$ is the carrying capacity. In the equation, the unimpeded growth rate is modeled by the first term $+r X$. The value of the rate $r$ represents the proportional increase of the population $\mathrm{X}$ in one unit of time. As the population grows, the second term, which is $-r X^{2} / K$, becomes larger than the first as some members of the population $N$ interfere with each other by competing for some critical resource, such as food or living space. This antagonistic effect is called the bottleneck, and is modeled by the value of the parameter $K$. Competition diminishes the combined growth rate, until the value of $X$ ceases to grow.

This implies that stock growth follows a parabolic growth curve. By defining $B_{1}$ as $k$ and $B_{2}$ as $(k / r)$, then eq. 1 could be rewritten as: $F\left(x_{t}\right)=B_{1} X_{t}-B_{2} X_{t}^{2}$. The natural equilibrium (maximum stock size) is reached when the stock of fish is equal to the environmental carrying capacity, $X=K$. That is why $K$ is termed as the maximum value that $X$ can reach. To obtain the maximum natural growth in equilibrium and the corresponding stock size, the first order derivative of eq. 1 should equal to zero:

$$
\frac{d X}{d t}=r\left(\frac{1-2 X_{t}}{K}\right)=0
$$

From this, it is obtained that the stock size where maximum growth of the fish stock occurs is at $\frac{K}{2}$.

It is assumed that the short-run harvest function follows the common Schaefer harvest function (Schaefer 1957), where the catch or harvest is proportional to the fishing effort and the stock level:

$$
\mathrm{H}=\mathrm{qEX}
$$

Where $H$ is the harvest, $q$ is the catchability coefficient and $E$ is the fishing effort. The catchability coefficient (q) expresses how effective the fishing effort is in relation to the stock level by a given fishing fleet.

The fishing effort, or sometimes just called effort, is a measure of the amount of fishing. Frequently some surrogate is used relating to a given combination of inputs into the fishing activity, such as the number of vessels, number of hours or days spent fishing, numbers of hooks used, kilometers of nets used, etc. (OECD 1998). Fishing effort 
adjustments simulated in this study correspond to capacity adjustments (changes in the number of vessels). Vessels in the fishery are assumed to be similar (homogeneous), and consequently have the same harvesting power and cost structure. In addition, fishing days by vessel and crew size per vessel are assumed to be constant.

If it is assumed that harvest (fishing) is done on a sustainable way, then the stock biomass that is removed by fishing has to be equal to the stock growth. Then the longterm harvest function is:

$$
H=F(X)=r X\left(1-\frac{X}{K}\right)
$$

Considering eq. 3 , harvest can be rewritten as:

$$
F(X)=r X\left(1-\frac{X}{K}\right)-q E X
$$

Then, the stock at equilibrium under a sustainable exploitation is equal to:

$$
X=\frac{K}{r}(r-q E)
$$

While the sustainable harvest level is determined by:

$$
H=q E \frac{K}{r}(r-q E)
$$

The gross revenue of a fishery is equivalent to the value of landings, and so equals quantity harvested multiplied by the price of fish (value of landings, VL). In the global fisheries model employed in the Sunken billions (Willmann et al. 2008), the average price of landings is a function of the global marine commercial biomass. The model uses a value of 0.2 for the elasticity of demand with respect to biomass, which means that if the biomass doubles, then the landings price increases by $20 \%$.

$$
\begin{aligned}
& \mathrm{VL}=\mathrm{pH} \\
& \mathrm{P}=0.92+0.2 \frac{X_{e}-X_{s q}}{X_{s q}}
\end{aligned}
$$

Then the value of landings curve will have the same shape as the sustainable harvest or yield curve, scaled up or down depending on the price. Following the GordonSchaefer bio-economic surplus production model (Gordon 1953, 1954), the value of landings' function is expressed in terms of effort (developing eq. 8 in terms of eq. 7).

In our application, it is assumed a constant marginal cost of effort for simplicity. This is based on the homogenous vessels assumption, where the vessels are added to (or taken out of) the fishery at the same cost as the previous one. The cost function is proportional (linear) to effort at a constant cost, a, per unit of effort. In Fig. 1 the total cost line (TC), is shown as an upward-sloping straight line. This corresponds to the traditional model where wages are assumed fixed, and consequently they are proportional to effort.

$$
\mathrm{TC}=\mathrm{a} \mathrm{E}
$$

Net profits, or vessel owner rents, can therefore be estimated from the difference between the revenues generated (value of landings) and the total costs. 


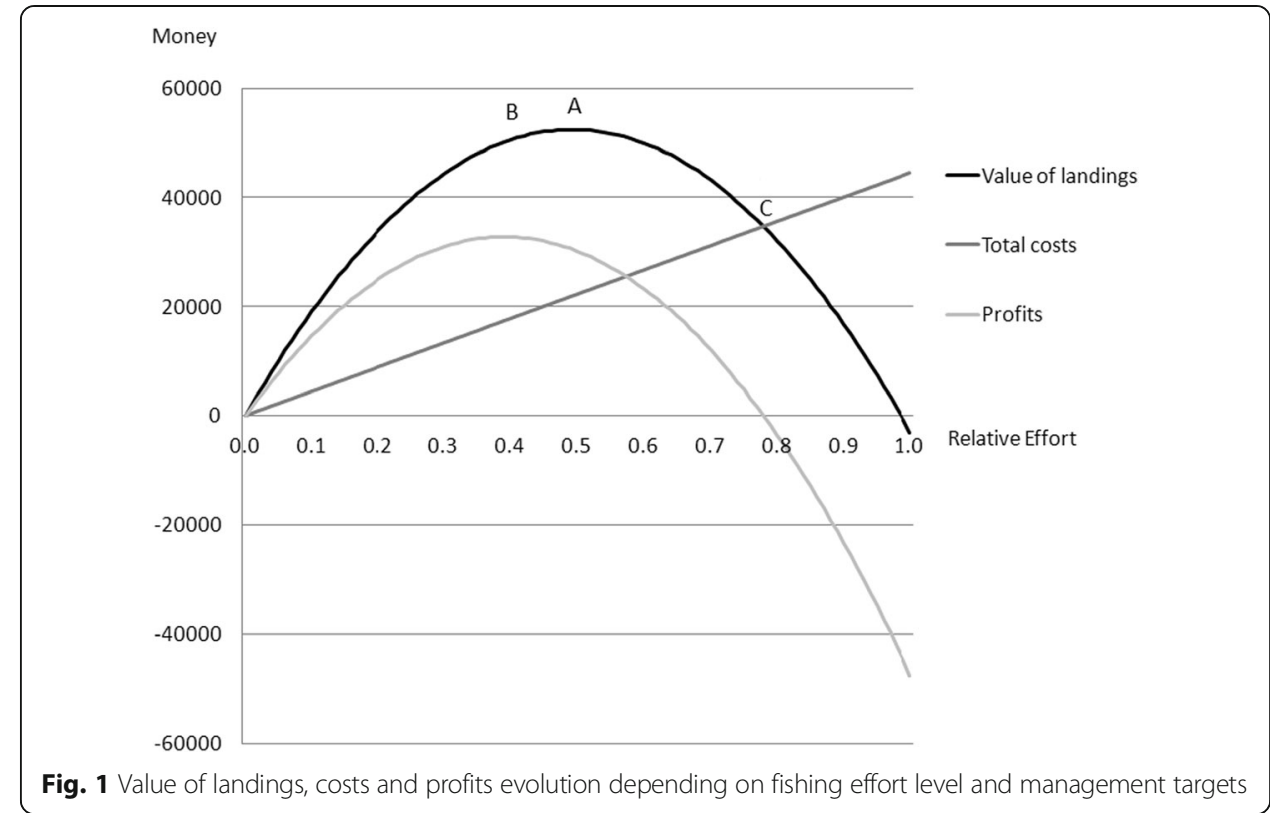

$$
\mathrm{NP}=\mathrm{VL}-\mathrm{TC}
$$

Fisheries rent is often considered as a "surplus" profit over and above that considered normal. In traditional models, the total fishery rent is equal to the profits and so the vessel's owner rent. The labor market is assumed to be in equilibrium, and consequently crew is remunerated with a fixed wage equal to the opportunity cost of labor.

From previous Fig. 1, different reference points (management targets) can be delimited. The Maximum Sustainable Yield (MSY) corresponds to the maximum harvest sustainable over time that can be obtained from a fish stock (point A in Fig. 1), which equals to the maximum growth of the fish stock. Maximum Economic Yield (MEY) is the sustainable harvest level that maximizes rents (equal to profits in this case), and so it corresponds to the effort level where there is the maximum distance between the revenue curve and the total costs line (point B in Fig. 1). The bio-economic equilibrium occurs when profits are 0 at equilibrium, and so at the harvest and effort levels when revenues are equal to the costs (point $C$ in Fig. 1). Theoretically, bioeconomic equilibrium takes place at open access, which is the condition where access to the fishery (for the purpose of harvesting fish) is unrestricted; i.e., the right to catch fish is free and open to all (OECD 2012).

However, when shared remuneration systems are taken into account, costs continue to be considered proportional to the number of vessels in the fleet (i.e., to the effort), except for labor costs that will depend on the revenues and the extent of costs deduced in each shared remuneration system. Therefore, total costs are disaggregated into labor costs (assumed to be 40\%, following Willmann et al. (2008)) and other costs that are proportional to fishing effort (60\%).

Wages from all remuneration systems are assumed to be equal at the current fishing effort level. The share rates of the different remuneration systems are identified so that labor costs at the current effort level are the same. 
Analyzing these 4 remuneration systems allow us to model the most common remuneration systems used in fisheries:

- Case 1: Fixed remuneration system: in a fixed remuneration system, wages are constant. Labor costs or crew costs (LC) are equal to the total crew gross remuneration, and are obtained multiplying the average fixed wage $\left(\right.$ wage $\left._{1}\right)$ by the total crew number (crew).

$L C_{1}=$ wage $_{1} \times$ crew

- Case 2: Shared remuneration system (proportional to revenues/catch): in such remuneration systems, wages are proportional to the value of landings (i.e., catch).

$L C_{2}=$ share_rate $\cdot V L$

- Case 3: Shared remuneration system (proportional to revenues minus operational costs): In this system, crew members obtain a share of the difference between the total value of landings and the variable (operating) costs (VC). Then crew costs are obtained as:

$L C_{3}=$ share_rate $\cdot(V L-V C)$

- Case 4: Shared remuneration system (proportional to profits): In this shared remuneration system, crew members obtain a share of the profits and hence, crew costs are calculated as:

$$
L C_{4}=\text { share_rate }_{4} \cdot N P
$$

When we refer to wages in this study, we refer to gross wages (i.e., including social security). This is because net wages would depend on each country's regulations (i.e. taxes), while gross wages are only influenced by the fishing activity. Average gross wage is proportional to the labor costs per unit of effort. The average crew wage at any effort level (e) and for each remuneration system (w) is equal to the total crew remuneration (labor costs, LC) divided by the crew number (crew) (see eq. 16). Crew number is unknown, but it is known to be proportional to effort (eq. 17). Therefore, by combining eqs. 16 and 17, crew wage can be expressed as a function of the labor costs per unit of effort (eq. 18). Hence, crew wages for any remuneration system at any effort level as a function of the current (status quo) wage, which is equal to the fixed wage, can be estimated as a function of labor costs and effort at status quo and at the effort level (eq. 19).

$$
\begin{aligned}
& \text { wage }_{e w}=\frac{L C_{e w}}{\text { crew }} \\
& \text { crew }=c E
\end{aligned}
$$




$$
\begin{aligned}
& \text { wage }_{e w}=\frac{L C_{e w}}{c E_{e}} \\
& \frac{\text { wage }_{e w}}{\text { wage }_{s q}}=\frac{L C_{e w} E_{s q}}{E_{e} L C_{s q}}
\end{aligned}
$$

Since crew wages can increase over the fixed wage in shared remunerations systems (assumed to be equal to the opportunity cost of labor), then labor rent can be created. Labor rent (or crew surplus): is estimated from the difference between crew wages and the opportunity cost of labor:

$$
\begin{aligned}
& L R=\text { wage }_{e w}-o c l \\
& L R=\text { wage }_{e w}-w a g e_{O A}
\end{aligned}
$$

where $o c l$ is the opportunity cost of labor.

\section{Data}

Biologic and economic parameters are estimated from the global marine fisheries model used in the Sunken billions report (Willmann et al. 2008).

Table 2 reports the biological parameters necessary to estimate the logistic function represented in eqs. 1, 2, 3, 4, 5, 6 and 7 .

Table 3 reports the economic parameters price and cost per unit of fishing effort ( $E$ costs) necessary to estimate eqs. $8,9,10$ and 11 . The average landings price depends on the global marine commercial biomass. The model uses a value of 0.2 for the elasticity of demand with respect to biomass (Willmann et al. 2008), which means that if the global biomass doubles, then the landings price increases by $20 \%$.

\section{Results}

Figure 2 summarizes the results obtained in the analysis using the parameters in Tables 2 and 3. A table with all the values is provided in the Appendix.

From Fig. 2 (and Table in the Appendix) it can be observed that the costs trajectories from the different remuneration systems 1, 2 and 3 meet at the current fishing effort level (relative fishing effort level of 1, as can be seen in Table 4), as assumed in the model. While the cost trajectory from remuneration system 4 follows the revenues curve, because it is assumed that there are no profits but all remaining revenues are split between the crew members.

The maximum difference between the costs trajectories from the different remuneration systems and the revenue curve (which equals to the maximum profits point) happens at different effort levels, depending on the remuneration system. While the maximum rents (equal to the gross value added) takes place at the same fishing effort level (relative fishing effort level of 0.45), the same for the maximum revenue (relative

Table 2 Biological parameters

\begin{tabular}{lr}
\hline Variable & Value \\
\hline K & 72.32 \\
q & 5.26 \\
q & 3.45 \\
\hline Source: own estimations from Sunken Billions report (Willmann et al. 2008)
\end{tabular}


Table 3 Economic parameters

\begin{tabular}{ll}
\hline Variable & Value \\
\hline Price & $0.92+0.2 \frac{X_{e}-X_{s q}}{X_{s q}}$ \\
E costs & 83.8 \\
\hline
\end{tabular}

Source: Sunken Billions report (Willmann et al. 2008)

effort level of 0.66), and the maximum harvest (MSY) (relative effort level of 0.76), that take place at the same fishing effort level independently of the remuneration system. The maximum revenue and the maximum production (MSY) do not take place at the same effort level because price increases when the available biomass increases, and consequently when landings decrease. It should be noted that the cost curve in case 4 follows the revenues curve, as it assumes that all profits are split between the crew members.

Thus, Table 4 reports the different relative fishing effort levels at which the different management objectives take place for each remuneration system.

At each management objective, and consequently at its corresponding fishing effort level, different fisheries rents can be obtained. Fisheries rents start from zero when there is no fishing and increase as fishing activity increases up to the MEY level, subsequently decreasing until bioeconomic equilibrium is reached, and rents are again zero (See Table 5).

Fisheries rent are composed of profits (owner rents) and labor rents. Because crew wages increase under shared remuneration systems, crew can capture part of the fisheries rent. The amount of fisheries rent captured by the crew will depend on the remuneration system. Table 6 shows the distribution of fisheries rent between owner and crew at each management objective under the different remuneration systems.

By definition, at the bioeconomic equilibrium level no profits are generated, but labor can still obtain some rents (depending on the opportunity cost of labor assumption). Under a shared remuneration proportional to revenues labor rent would be 4.02 billion dollars, while under a shared remuneration proportional to revenues minus operational

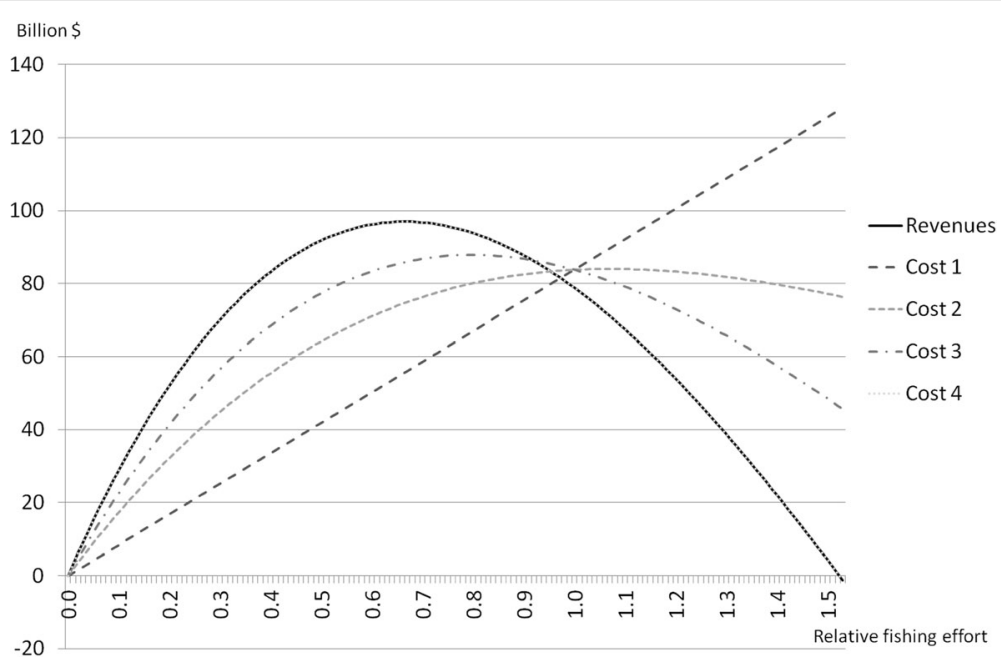

Fig. 2 Revenues, costs and profits evolution depending on remuneration system and fishing effort level (billion USD) 
Table 4 Effort level for each management objective and remuneration system

\begin{tabular}{lccccc}
\hline & & Costs case 1 & Costs case 2 & Costs case 3 & Costs case 4 \\
\hline Max rents (MEY) & A & 0.45 & 0.45 & 0.45 & 0.45 \\
Max profits & B & 0.45 & 0.45 & 0.43 & - \\
Max revenues & C & 0.66 & 0.66 & 0.66 & 0.66 \\
MSY & D & 0.76 & 0.76 & 0.76 & 0.76 \\
Open access & E & 0.97 & 0.95 & 0.91 & - \\
Current & F & 1.00 & 1.00 & 1.00 & 1.00 \\
\hline
\end{tabular}

costs labor rent would be $\$ 10.72$ billion. At MEY, profits under fixed remuneration systems are $\$ 50.34$ billion, while labor rent is null; under a shared remuneration proportional to revenues, profits are $\$ 28$ billion and labor rent $\$ 22.34$ billion; under a shared remuneration proportional to revenues minus operational costs, profits are $\$ 14.75$ billion and labor rent $\$ 35.59$ billion; and under a shared remuneration proportional (equal) to profits, profits are null and labor rent $\$ 50.34$ billion.

Table 7 reports the average crew wages as a function of current wage (equal to fixed wage) per remuneration system and management objective.

Table 7 shows that average crew wages can increase under shared remuneration systems when more restrictive management objectives are achieved (i.e., MSY, MEY), and consequently when fish stocks improve. Thus, when fishing at MSY, wages are a 59, 94 and $93 \%$ higher than current level under shared remuneration proportional to revenues, revenues minus operational costs and profits, respectively. Similarly, at MEY average wages are a 148, 236 and $232 \%$ higher than current level under shared remuneration proportional to revenues, revenues minus operational costs and profits, respectively.

Average wages increase when fishing effort decreases, and so when stock size (biomass at sea) increases. Consequently, maximum average wages occur at the lowest fishing effort level above zero. Thus, attempting to maximize average crew wages is an unrealistic management objective if not defined for a certain crew number and time period.

\section{Discussion}

Shared remuneration systems have traditionally proven, and continue to prove, useful in fisheries because they provide an incentive to crew when their work is sometimes difficult to monitor. This way, rents and risks are shared between the vessel owner and the crew; the vessel owner does not have to dole out remuneration at fixed levels if catches are low (Acheson 1981; McGoodwin 1991). However, when the economic performance of a fleet increases, crew wages increase significantly and when this happens, the crew are able to capture some of the fishery rents (extraordinary profits).

Table $\mathbf{5}$ Total rent evolution (billion USD)

\begin{tabular}{lcccc}
\hline & Costs case 1 & Costs case 2 & Costs case 3 & Costs case 4 \\
\hline MEY & 50.34 & 50.34 & 50.34 & 50.34 \\
Max profits & 50.34 & 50.34 & 50.21 & - \\
Max revenues & 41.68 & 41.68 & 41.68 & 41.68 \\
MSY & 31.72 & 31.72 & 31.72 & 31.72 \\
Current & -4.95 & -4.95 & -4.95 & -4.95 \\
Open access & 0.00 & 4.02 & 10.72 & - \\
\hline
\end{tabular}


Table 6 Profit and labour rent evolution (billion USD)

\begin{tabular}{lllll}
\hline & Costs case 1 & Costs case 2 & Costs case 3 & Costs case 4 \\
\hline MEY & $50.34 ; 0.00$ & $28.00 ; 22.34$ & $14.75 ; 35.59$ & $0.00 ; 50.34$ \\
Max profits & $50.34 ; 0.00$ & $28.00 ; 22.34$ & $14.78 ; 35.43$ & $0.00 ;-$ \\
Max revenues & $41.68 ; 0.00$ & $22.57 ; 19.11$ & $11.25 ; 30.43$ & $0.00 ; 41.68$ \\
MSY & $31.72 ; 0.00$ & $16.64 ; 15.08$ & $7.70 ; 24.02$ & $0.00 ; 31.72$ \\
Current & $-4.95 ; 0.00$ & $-4.95 ; 0.00$ & $-4.95 ; 0.00$ & $0.00 ;-4.95$ \\
Open access & $0.00 ; 0.00$ & $0.00 ; 4.02$ & $0.00 ; 10.72$ & $0.00 ;-$ \\
\hline
\end{tabular}

In this paper, we compared the fixed remuneration system with three different shared remuneration systems commonly used in fisheries: (1) proportional to revenues, (2) proportional to revenues minus operational costs and (3) proportional to profits. By investigating these three shared remuneration systems with a simple bioeconomic model, we were able to analyze the entire spectrum of shared remuneration systems. The shared remuneration proportional to revenues minus operational costs (case 3) may be the most standard remuneration system in fisheries; while the shared remuneration proportional to revenues (case 2) represents the extreme case where no costs are deducted from revenues and the shared remuneration proportional to profits (case 4) represents the extreme case where all costs are deducted. So, any particular shared remuneration system can be represented, depending on the number of costs items that are deducted from revenues; e.g., if less costs items are deducted than in case 3, then the remuneration system will behave somewhere in the middle between cases 2 and 3 .

Results confirm, as shown in the Sunken Billions report (Willmann et al. 2008), that global marine fisheries are underperforming of about $\$ 50$ billion per year, ${ }^{5}$ and society could capture a substantial part of them by improving fisheries management (e.g., by fishing at maximum rents or MSY points). However, these $\$ 50$ billion per year could not be directly translated into profits, because crew members can capture part of the fisheries rent in shared remuneration systems once the economic performance improves. For example, if global fisheries would be managed at MSY, it could be obtained about $\$ 32$ billion per year ( $\$ 50$ billion per year when maximizing rents). If labor would be remunerated with fixed salaries, then these $\$ 32$ billion per year would become part of the profits (capital rent); instead if crew are remunerated with shared remuneration systems 2, 3 and 4, then profits would not be $\$ 32$ billion per year but $\$ 17$ billion, $\$ 8$ billion and $\$ 0$ billion per year, respectively. The rest of the fisheries rents become part of the labor rents.

Similar results were obtained for the Bay of Biscay nephrops fishery where crew members receive a shared salary as in case 3. Guillen et al. (2015) estimated that if

Table 7 Crew wages as a function of current wage (equal to fixed wage)

\begin{tabular}{lcccc}
\hline & Costs case 1 & Costs case 2 & Costs case 3 & Costs case 4 \\
\hline MEY & 1.00 & 2.48 & 3.36 & 3.32 \\
Max profits & 1.00 & 2.48 & 3.46 & - \\
Max revenues & 1.00 & 1.86 & 2.38 & 2.38 \\
MSY & 1.00 & 1.59 & 1.94 & 1.93 \\
Current & 1.00 & 1.00 & 1.00 & 0.85 \\
Open access & 1.00 & 1.12 & 1.34 & - \\
\hline
\end{tabular}


the nephrops fishery recovers to MSY, salaries would increase by $95 \%$ and by $320 \%$ if it reaches MEY; while for global marine fisheries, wages would increase by 94 and $236 \%$, respectively.

In shared remuneration systems, labor costs are independent of the crew number, and consequently the average wage depends on the crew number. While in fixed remuneration systems, the average wage is fixed (constant), and so labor costs are proportional to the crew number.

Our results also confirm that the fishing effort required to achieve certain management objectives may be affected by the crew costs, and consequently by the remuneration system in place. Because under shared remuneration systems costs are not proportional to fishing effort, the effort level required to achieve some economic based management objetives (e.g., maximum profits and maximum employment) vary depending on the remuneration systems. While, the effort level required to achieve other management objectives (e.g., MSY and maximum rents) is independent of the remuneration system.

When looking at the bioeconomic equilibrium (open-access point) in Fig. 1, the fixed remuneration is less conservative than the shared remunerations. In other words, the bioeconomic equilibrium is reached at a higher fishing effort level for the fixed remuneration. However, in Guillen et al., (2015), fixed remuneration was found to be more conservative, mainly as a result of the initial value given to the opportunity cost of labor:

- When the fishery is in bioeconomic equilibrium (no profit or losses) and so the opportunity cost of labor is assumed to be equal to the bioeconomic equilibrium salary, then the open access level is the same for all remuneration systems.

- When the fishery is having profits and the opportunity cost of labor is assumed to be higher than the bioeconomic equilibrium salary, then the fixed remuneration is less conservative.

- When the fishery is having losses and the opportunity cost of labor is assumed to be lower than the bioeconomic equilibrium salary, then the fixed remuneration is more conservative.

Similarly, maximum profits are achieved at different fishing effort levels. When it is assumed that the fisheries follow a logistic model, the fixed salaries are the less conservative. Instead, then a different behavior of the fishery is assumed, as in Guillen et al., (2015), where a hockey stick model is used, then the fixed salaries were more conservative.

In addition, since in most common shared remuneration systems (case 2 and 3) the fishing effort that maximizes profits is different than the one that maximizes labor rents; consequently, there is a principal-agent problem if vessel owners are not present in the fishing vessels (Eisenhardt 1989; Vestergaard 2010). When a vessel owner is not present, crew would prefer to increase their fishing effort, if they do not have to bear the operational costs, in order to increase their revenues. However, in the global perspective, taking into account the shared remuneration systems analyzed, when vessel owners are not present, crew would prefer to reduce overall fishing effort in order to maximize their rents. Moreover, in shared remuneration systems where only the vessel owner bears the capital and investment costs (cases 2 and 3), Hannesson (2007) showed that it could lead to non-optimal (i.e., lower) levels of investment. Indeed, in many 
fisheries, vessel owners pay all investment costs, but the crew receives part of the increases in catch that result (Alexander 1973).

The share rate and the costs items that are deducted to the value of landings may change between countries, fleets, fisheries and vessels, as well as over time. For example, in the Netherlands, mainly fuel cost is deduced to the value of landings (Bartelings et al. 2015); while in France and Spain fuel, ice, food, and bait costs are commonly deduced (Lleonart et al. 1999, 2003; Maynou et al. 2006; Macher et al. 2008). Same happens for quota costs; in Iceland and Australia quota costs are often borne entirely by the vessel owner while in the UK quota costs are shared between the owner and the crew, along with other variable operating costs (Hatcher 2010). Moreover, sometimes costs items deducted from revenues and share rates may vary between vessels in the same fleet. Indeed, in the Bering Sea/Aleutian Island crab fisheries, about $80 \%$ of the vessels share quota costs with the crew, while about 20\% do not (see Abbott et al. 2010 for more examples for that particular US fishery).

The analysis assumes a fixed share rate of the crew part. But the share rate can change if there are significant changes in the fishing conditions: (i) important new investments (e.g., electronic equipment, introduction of steam-driven fishing vessels in the Basque Country in Spain led to decrease the crew share to 30\% - Pascual Fernandez 1999), (ii) significant variations in fuel prices (Matthiasson 1997), (iii) changes in management (i.e., introduction of ITQs (Squires et al. 1995; Guyader and Thebaud 2001)). Thus, the share remuneration systems have proven to be a self-adaptive and timeconsistent remuneration system that can adapt to changing circumstances (Hämäläinen et al. 1990; McConnell and Price 2006).

So, the share rate could be adjusted either by vessel owners to capture a larger part of the rents or to keep the crew during the bad years. It could be thus possible that once a stock starts recovering, vessel owners change the share rate to increase the vessel owner share (and consequently decrease the crew share), in order to capture more rent once crew wages start to increase. If the share rate could be continually revised to reflect equilibrium in the labor market, the crew would always get the opportunity cost of their labor (Hannesson 2007), and consequently results would be similar to the ones obtained assuming constant wages. This way, the share system would still serve the purpose of an incentive contract to ensure that crew members exert the necessary effort to obtain a wage equal to their opportunity wage (Hannesson 2007). While the vessels owners would capture all the rents (i.e. accumulate all the capital).

However, there are also cases where the share rate has not been revised despite significant changes in a fishery. For example, with the implementation of catch shares in the Bering Sea/Aleutian Island crab fisheries, the share rate has remained practically unchanged leading to substantial increases in the remuneration for many crew members (Abbott et al. 2010). Therefore, whether a remuneration system in a fishery behaves as fixed or shared, and consequently the possibility for the crew to capture part of the vessel owners rent, depends in part on the fixity of the share rate, and so on the negotiation capacity of each of the parts.

However, in recent years, an increase in the use of the fixed remuneration systems worldwide has been observed (Thuy et al. 2013; Ünal personal communication). This is mainly a result of lower and more uncertain catches and revenues, as stocks are becoming more overexploited. Increased stock overexploitation and overcapacity (fishing 
effort level increases, i.e., moving rightwards in Fig. 1) lead to lower wages and so more difficulties to find crew when wages are below the opportunity cost of labor. In that case, crew would switch jobs to their best alternative job possible. In this sense, Willmann et al. (2008) reported that more than $75 \%$ of the fish stocks were underperforming in economic terms in 2004, leading to $\$ 5$ billion losses (without accounting for the potential of global fisheries). Accordingly, FAO (2014a) reports that the number of stocks fished at unsustainable biologic levels peaked at $32.5 \%$ in 2008 , since then declined slightly to $28.8 \%$ in 2011 .

The current low salaries ${ }^{6}$ in the fishing sector also explain the increasing use of foreign and unskilled crew in many fisheries worldwide. Foreign crew is often more risk averse as fishing is often the sole source of income, and so would prefer fix wages (Nguyen and Leung 2009). In addition, due to the low wages it is difficult to find skilled labor, and so is replaced with unskilled labor. In these circumstances, vessel owners are also not willing to pay more for unskilled labor; while the availability of unemployed unskilled labor also works as an incentive for crew to work hard. Thus, the increase of fish stocks being overfished worldwide (Worm et al. 2009; FAO 2014a), the increasing use of foreign manpower and the industrialization of fishing fleets may reduce the use of shared remuneration systems.

Shared remuneration systems have a general functioning more similar to conventional remuneration systems where workers are paid a piece rate (an amount of money that relates to their output), rather than the time they input (i.e., fixed remuneration systems). In addition, in shared remuneration systems the crew share is often divided between the crew in a non-homogenous way where crew receive different wages based on their ranks or grades. Hence, wages reflect differences in marginal productivity inside the crew. In some fisheries, crew members may receive higher wages on the basis of age and experience (Breton 1973); while, in other cases all crew equally receive the same amount, regardless of experience (Lofgren 1972; Colloca et al. 2003). In some fisheries, mostly artisanal ones, if a crew member owns the fishing gear, he/she may obtain a larger part of the share (McCall Howard 2012). When fishing success depends on highly skilled specialists, these specialists may receive a higher percentage of the catch (Prins 1965; Wadel 1972). For example, in the Moroccan purseseine fishery, the captain receives on average 4.5 times the wage of normal fishermen (deckhand), the mechanic 2.37 times, the person in charge to mend the nets 2 times, and the cook 1.25 times the wage of a deckhand (see Kamili (2006) for a more detailed explanation). Purse-seiners in Greece remunerate the captain and the mechanic with 2.5 times the wage of deckhand each, and crew knowing how to mend nets and on the stern receive 1.5 times more. While in Brazil, on an 18tonne vessel, the captain receives on average 4.5 times, the mechanic 2.5 times, and the cook 1.5 times the wage of deckhand (Giasson 1981). So, the division of the crew share among the crew members behaves as a tournament contract where crew members are rewarded by their rank in the organization (Lazear and Rosen 1981; Green and Stockey 1983).

\section{Conclusions}

If a more rational fisheries management is in place and stocks recover, this may not be fully translated in an increase in the profitability of the fishing sector. In 
fact, in most fisheries worldwide, crew members are remunerated through different shared remuneration systems rather than a fixed wage. In shared remuneration systems, crew wages can be significantly higher than fixed wages (i.e., more than double) when the stocks and consequently the economic performance of vessels improve. This leads the crew to capture part of the fisheries rents as crew rents. These particular remuneration systems suit the needs of the fishing sector by providing incentives to the workers, which probably has been the historical reason for its wide adoption and maintenance.

However, the use of the shared remuneration systems worldwide appears to have decreased in recent years because of lower and more uncertain catches and revenues due to overfished fish stocks (Worm et al. 2009; FAO 2014a), the industrialization of fishing fleets (Thuy et al. 2013; Ünal personal communication), increases in fuel prices that lower the economic performance, and the difficulties to find and attract crew.

Hence, it is important to understand the particularities and variety of the shared remuneration systems in the fishing sector and the implications the remuneration systems have on crew wages, the firm's economic performance and the optimal fishing effort level.

\section{Endnotes}

${ }^{1}$ When assuming prices to be constant in relation to quantity landed and size of the individuals landed

${ }^{2}$ It is also an extended practice worldwide that the crew receives a small fraction of the catch. Depending on the country and fishery, this fraction of the catch could be a part of the main species or based on low value species or small size and damaged individuals. It is called "morralla" in Spain (Alemany and Álvarez 2003; Reglero and Morales-Nin 2008; Samy-Kamal et al. 2014) and Cuba (Baisre 2000), "godaille" in France (Jorion 1979; Del Sol et al. 1998), French Guyana (Guéguen 2001) and Martinique (Failler 1996), and "fakira" in Morocco (Baddyr and Guénette 2002; Kamili 2006).

${ }^{3}$ From ILO (2004) it seems that to the proportion of the catch sale could be also deducted operational costs.

${ }^{4}$ The distinction between remuneration of labour and remuneration of the invested capital is not systematic for many units, especially for those in which the owner is also the fisher onboard (Boncoeur et al. 2000) which is the case for most small scale fleets in Europe (Guyader et al. 2013) and worldwide (Thuy et al. 2013).

${ }^{5}$ As pointed out by Willmann et al. (2008), losses to the global economy from unsustainable exploitation of living marine resources substantially exceed these estimates. These estimates exclude losses related to recreational fisheries, marine tourism and illegal fishing, as well as the economic contribution of dependent activities such as fish processing, distribution, and consumption. It also excludes the value of biodiversity losses, pollution and greenhouse gas emissions.

${ }^{6}$ In some countries, wages in the fisheries sector have been below the minimum legal salary during some months. It should be also taken into account the wages by hour at sea, considering the long time spent onboard together with the harsh and risky working conditions, instead of absolute wages per year. 


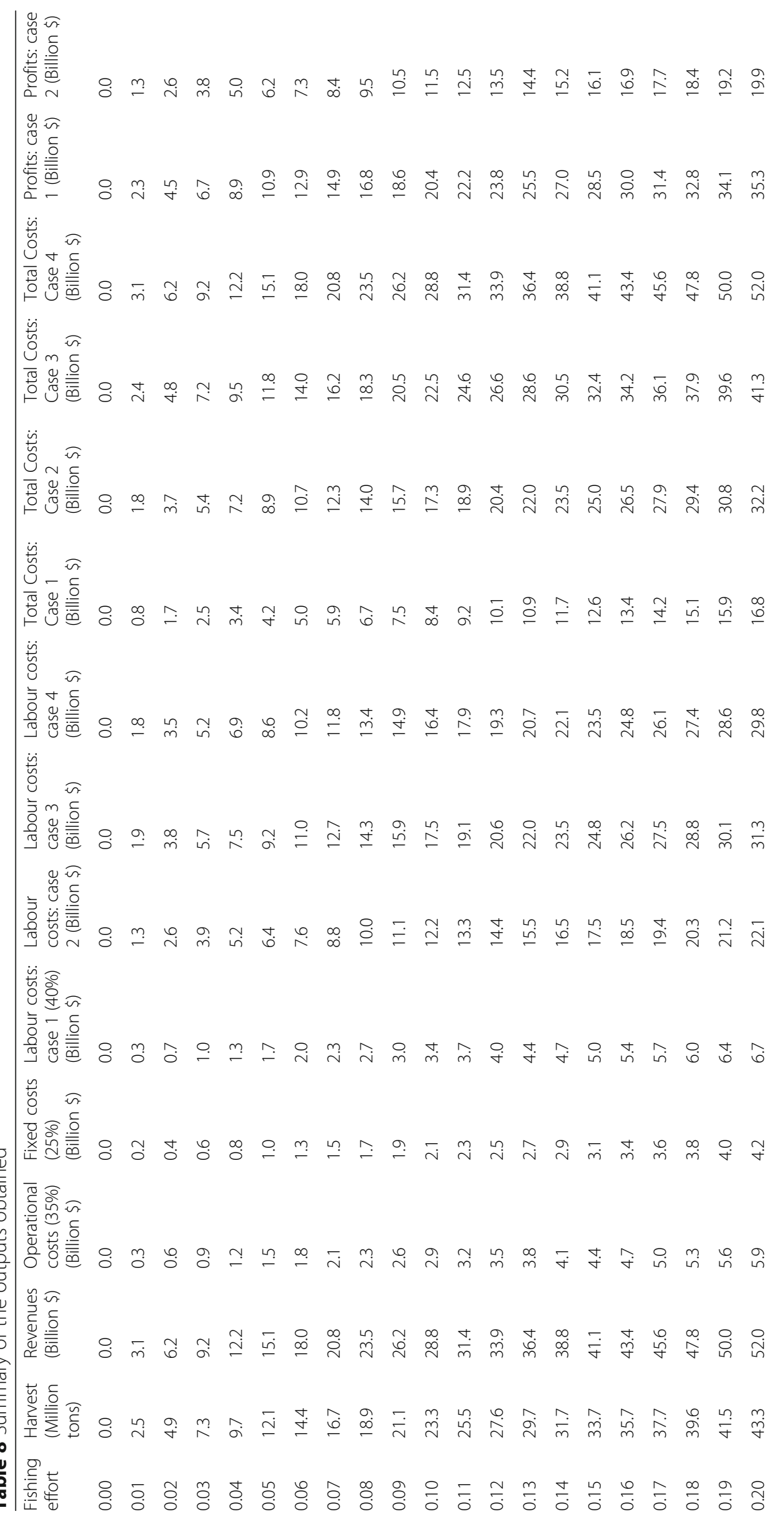


䋡 方

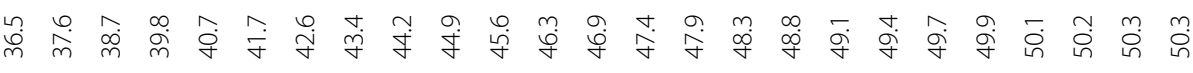

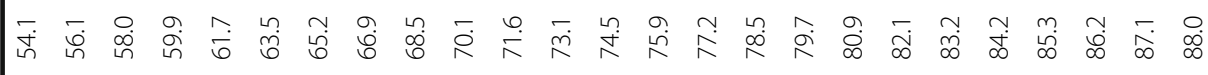

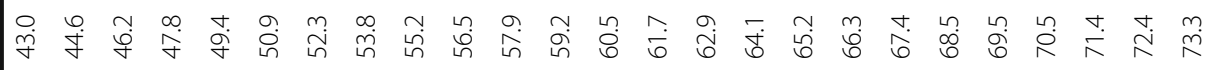

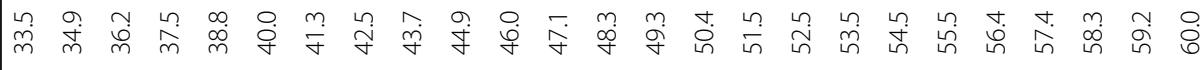

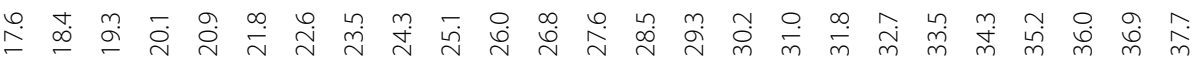

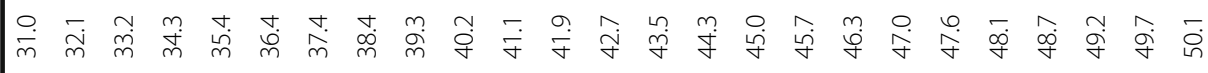

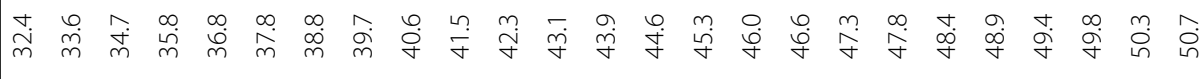

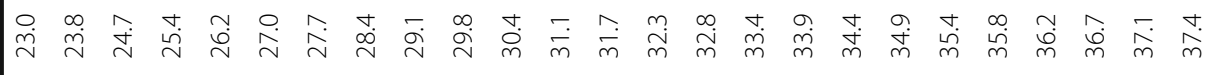




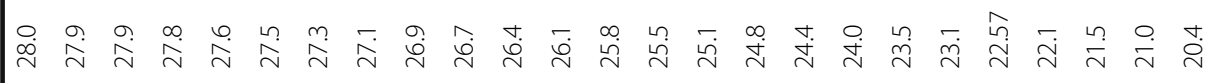

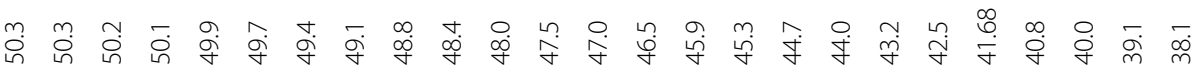

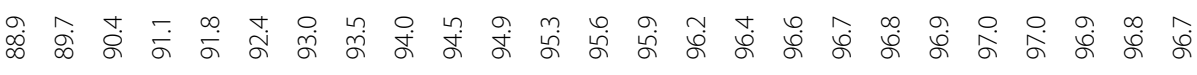

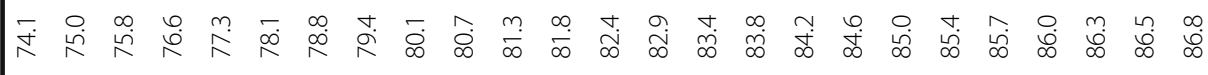

商部

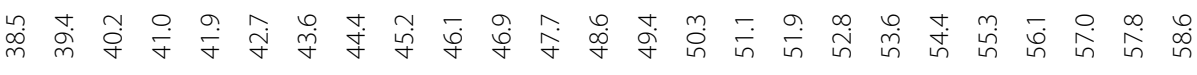

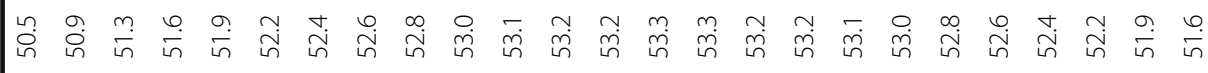

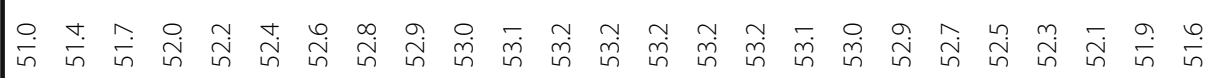

少

苞

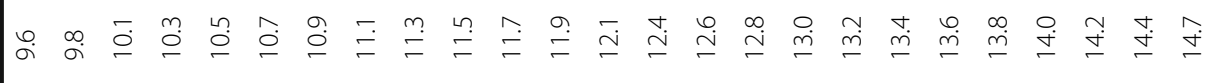

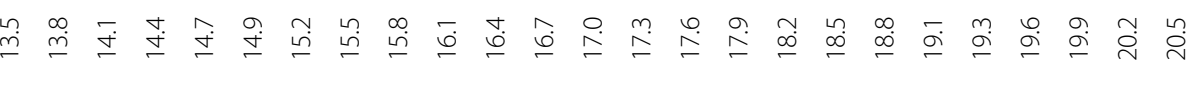

ळ

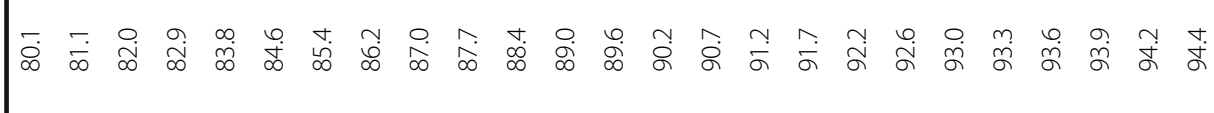

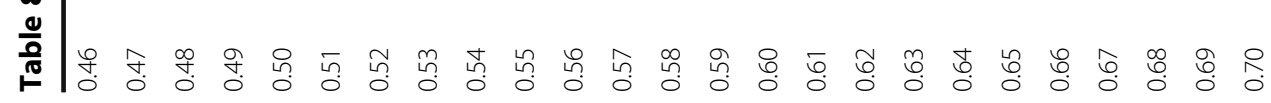




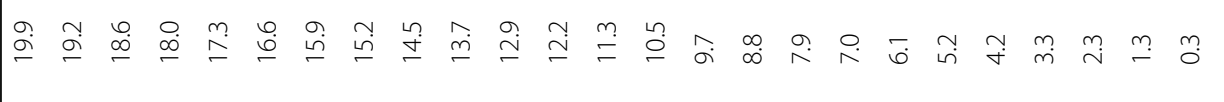

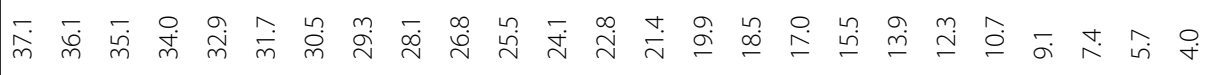

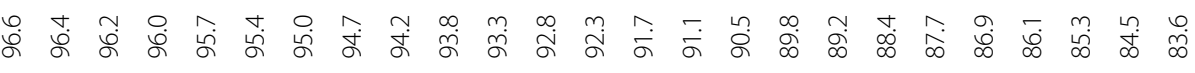

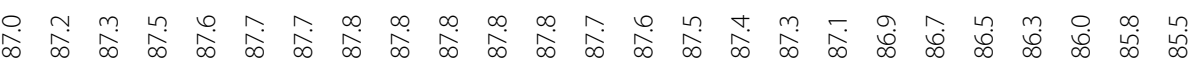

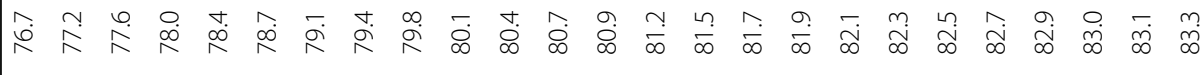

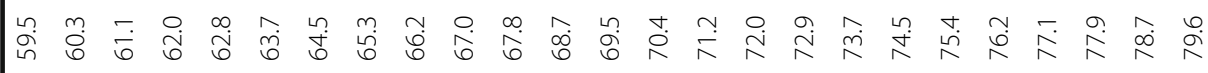

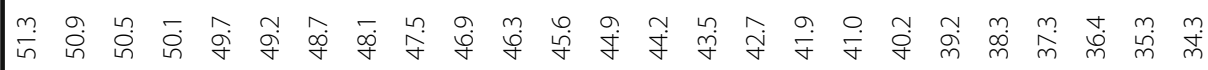

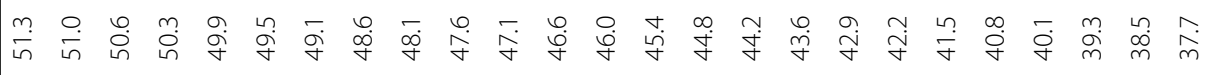

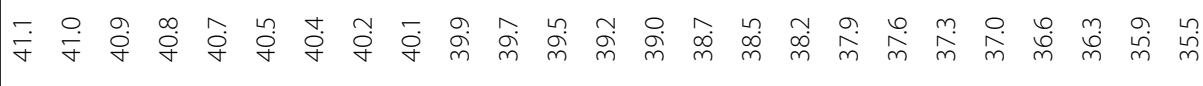

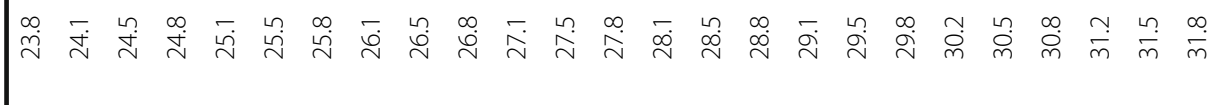

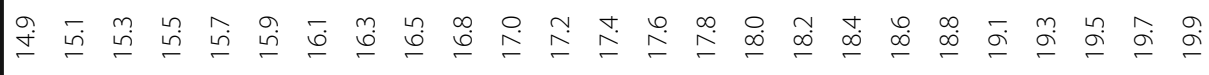

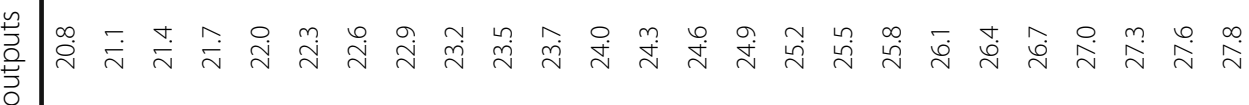

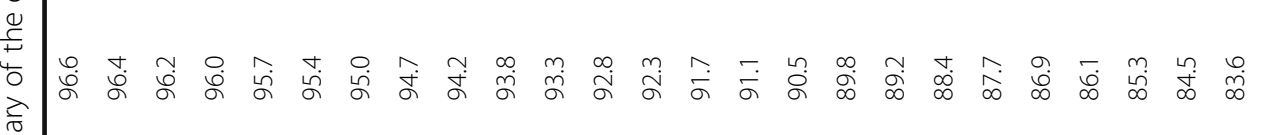

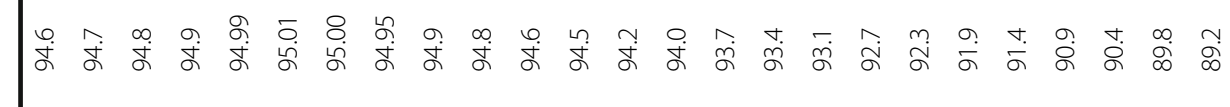

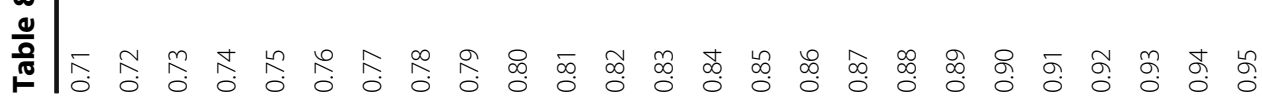




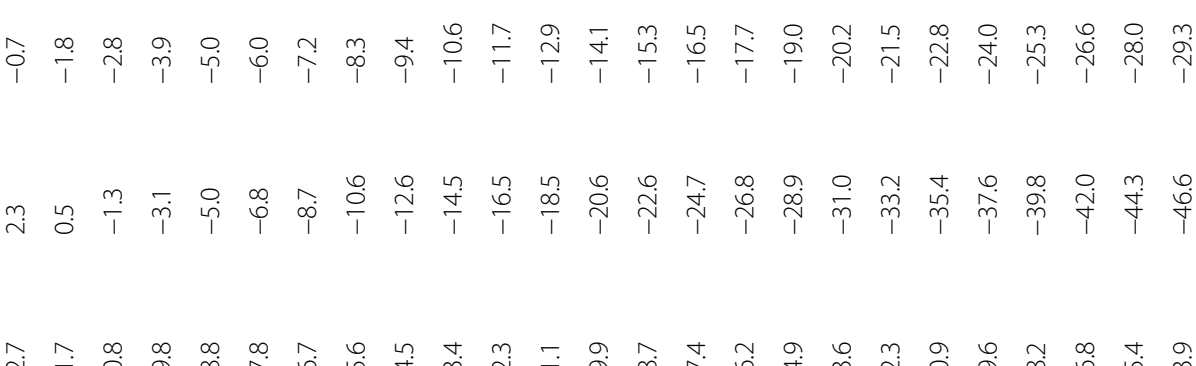

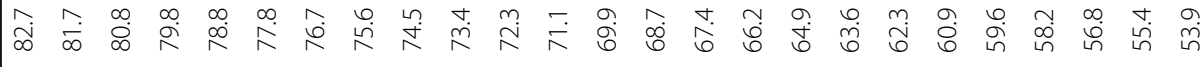

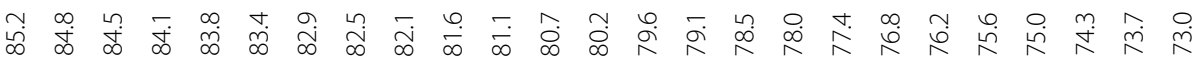

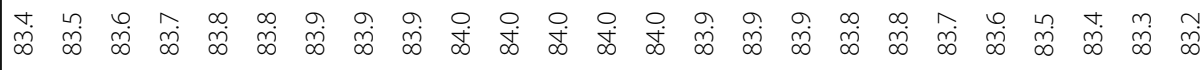

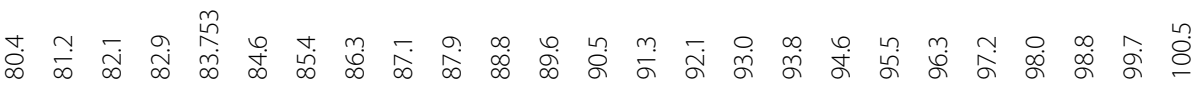

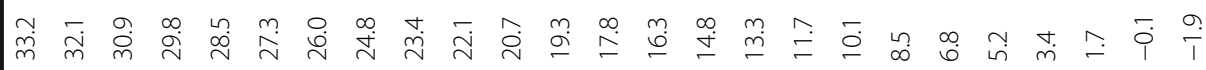

ô

惌

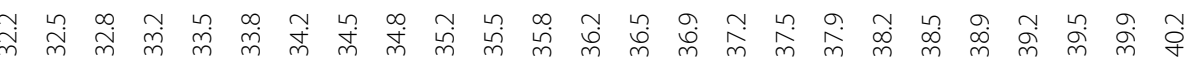

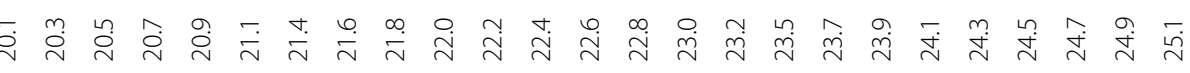

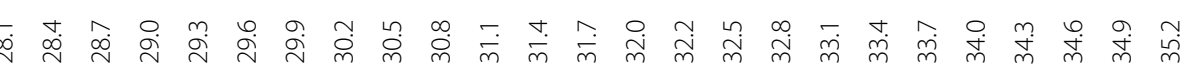

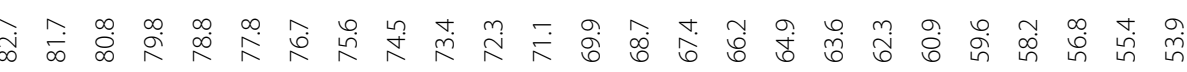

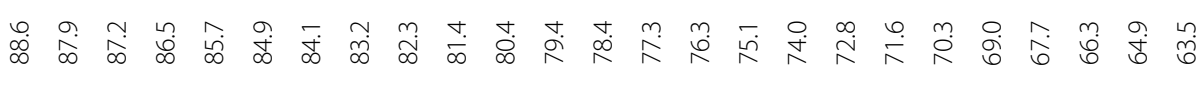

o 


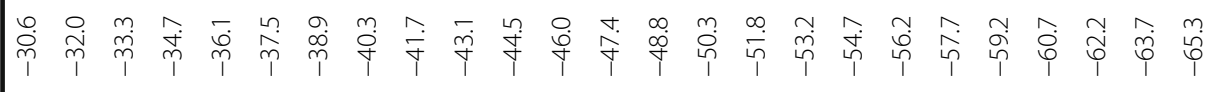

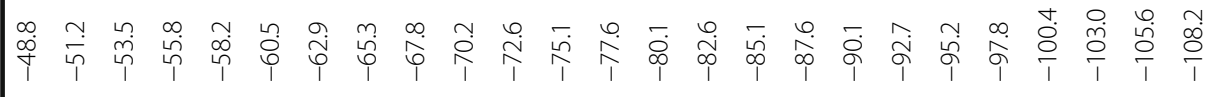

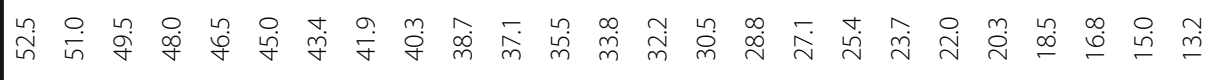

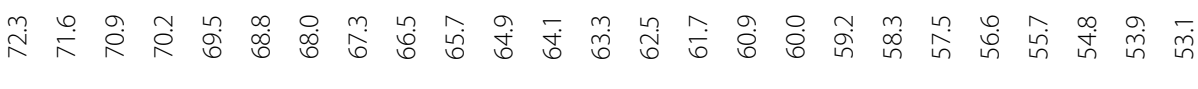

స

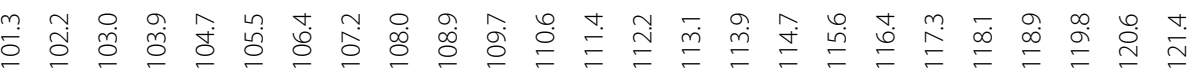

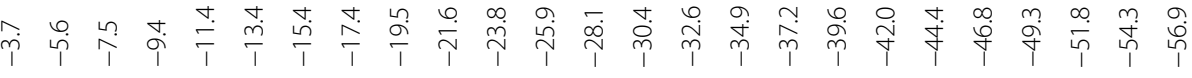

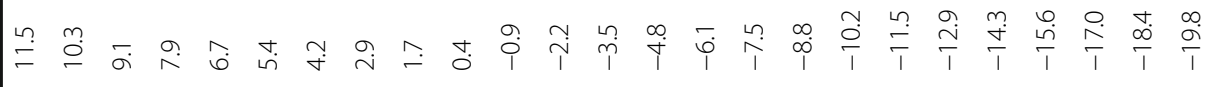

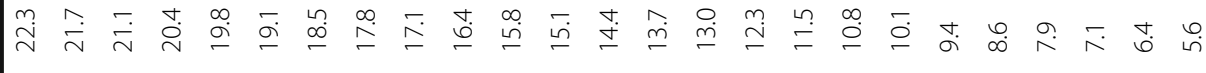

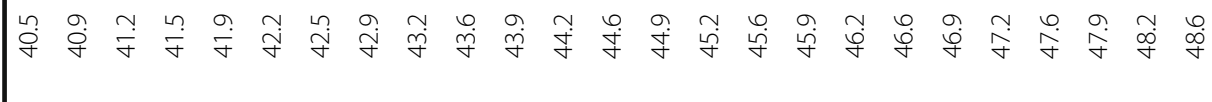

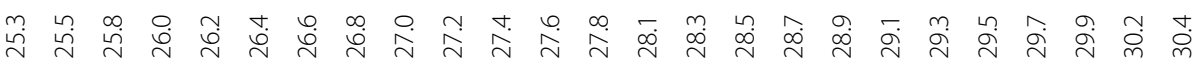

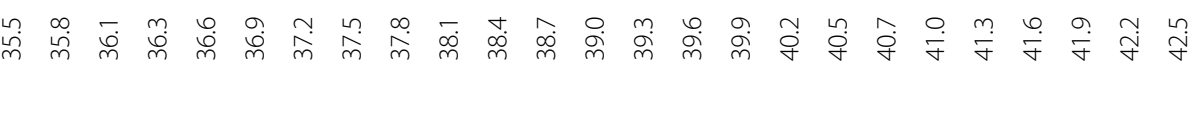

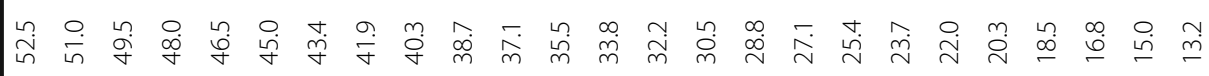




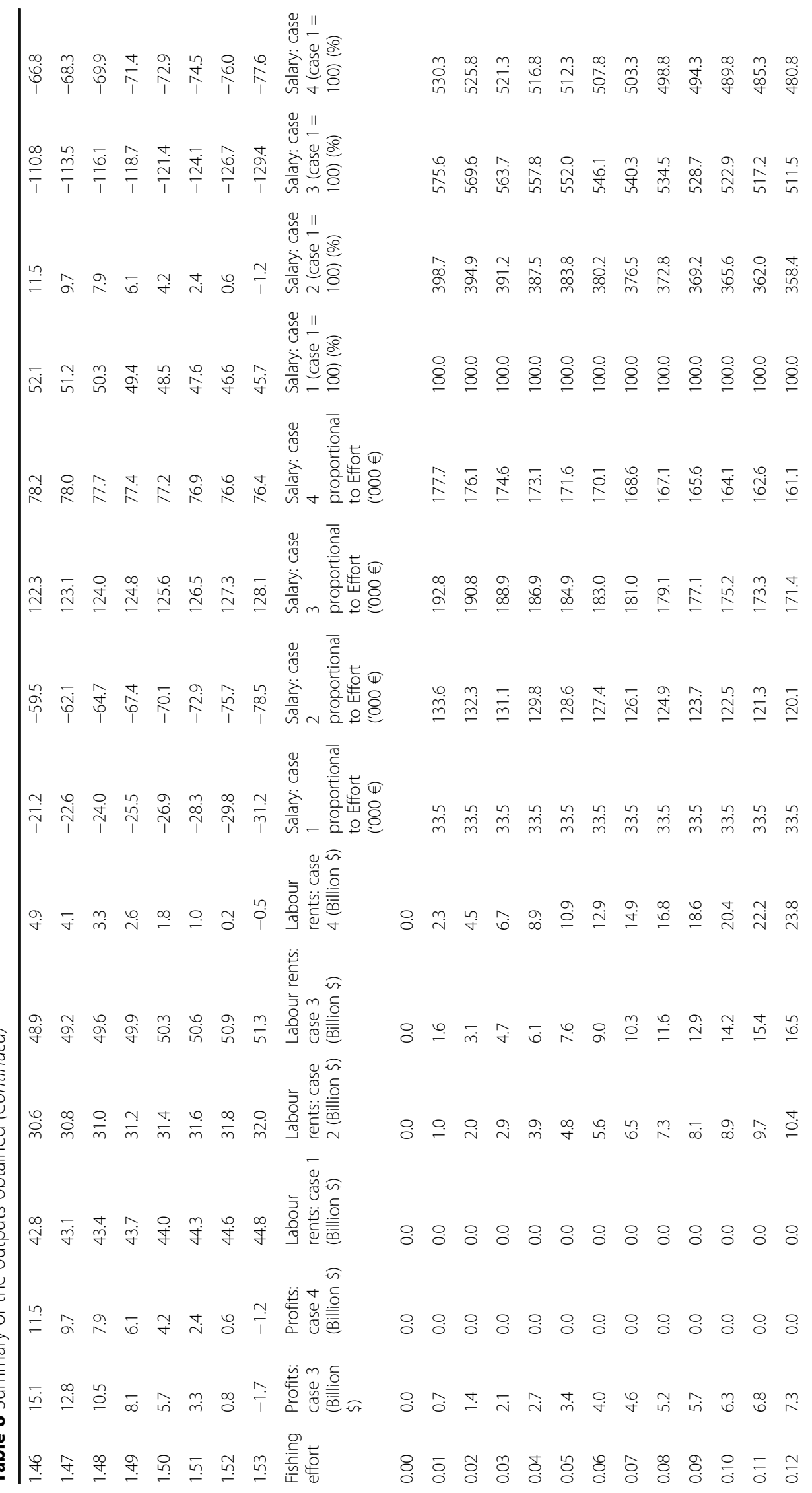




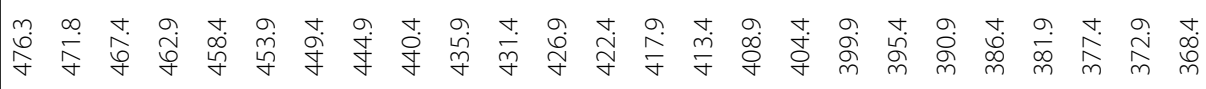

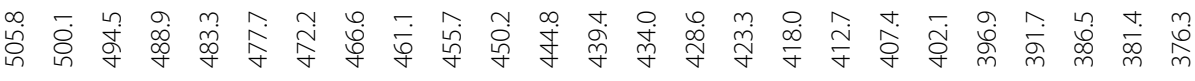

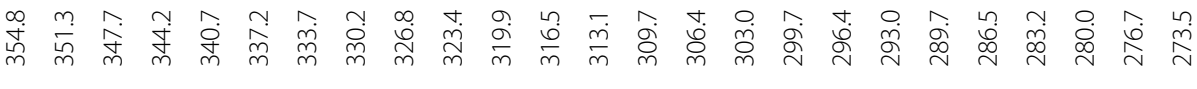

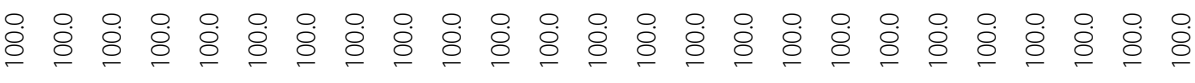

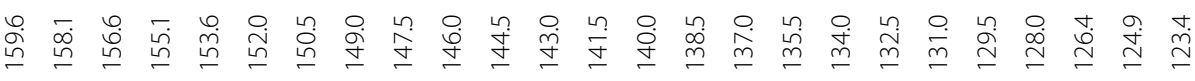

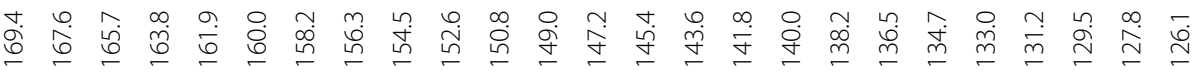

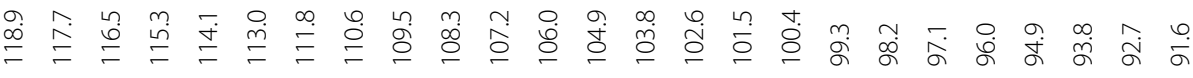

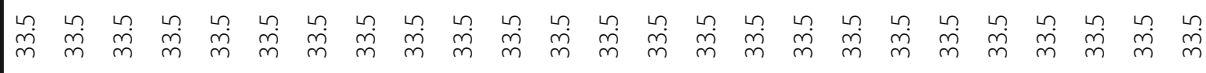

崩 穴点

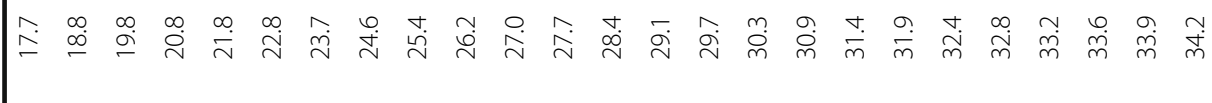

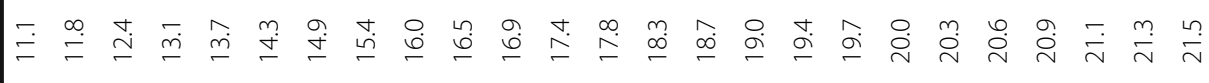

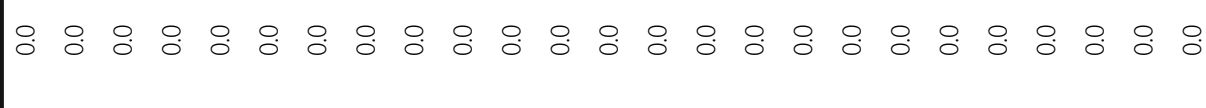

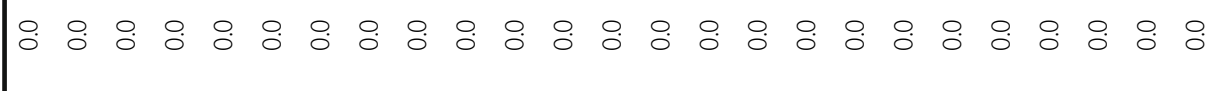
悉

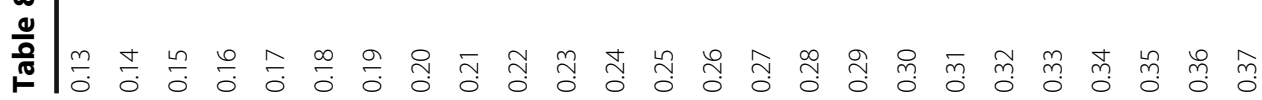




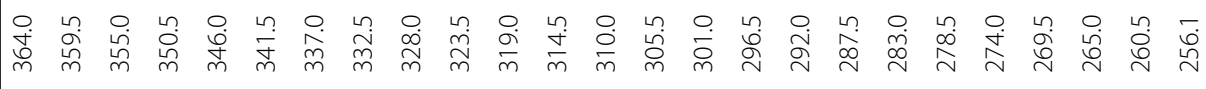

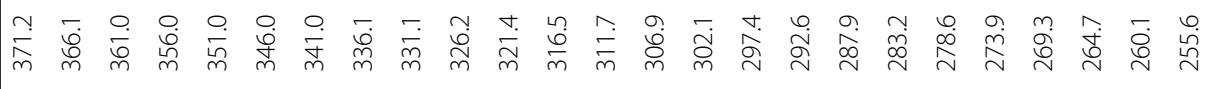

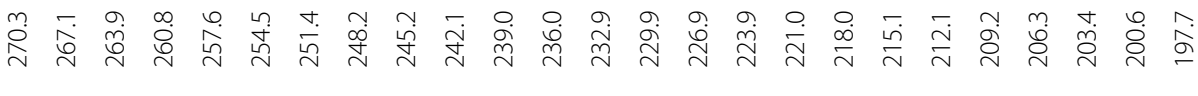

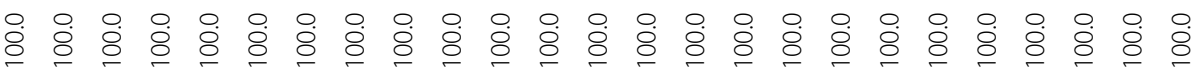

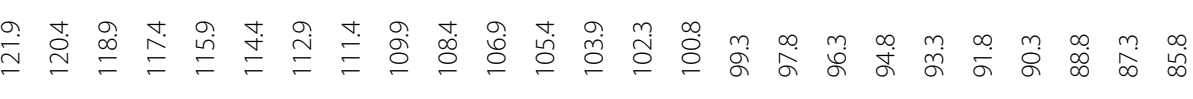

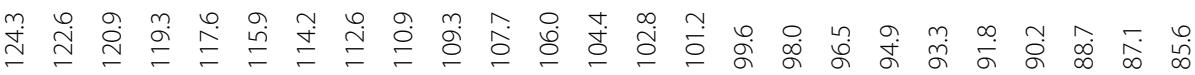

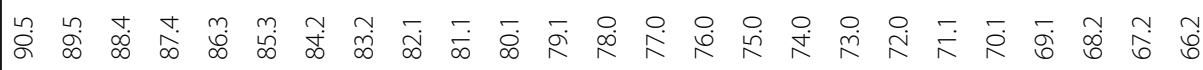

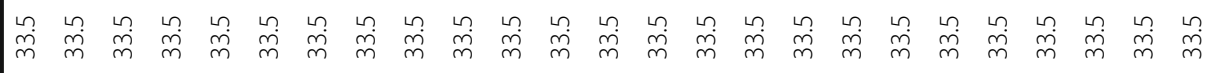

字 字

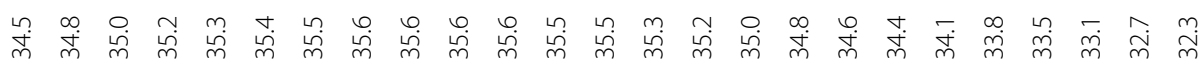

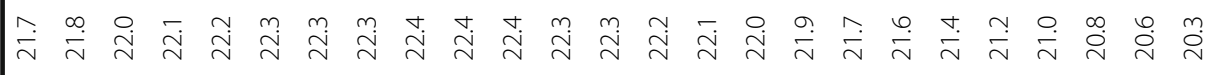

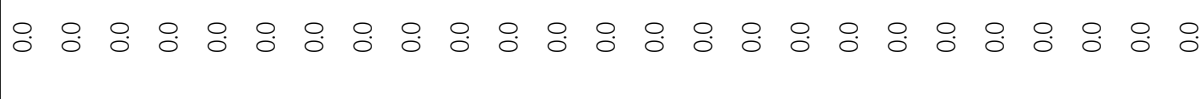

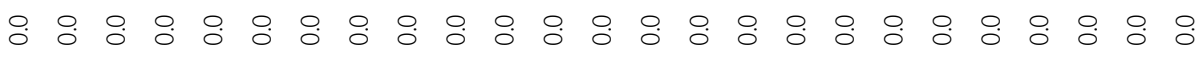

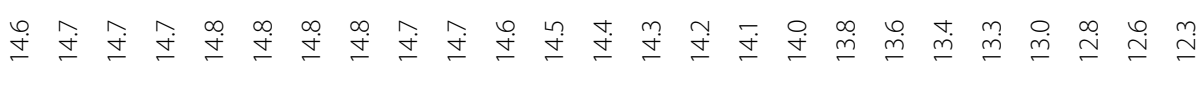

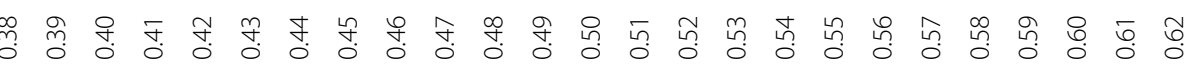




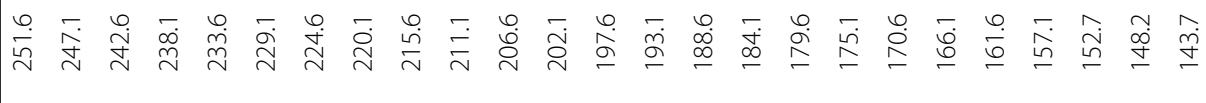

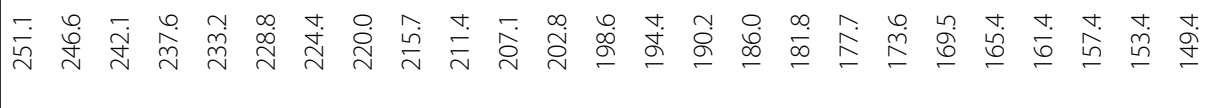

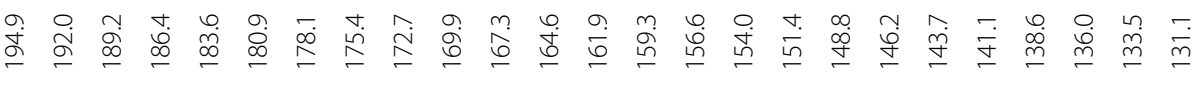

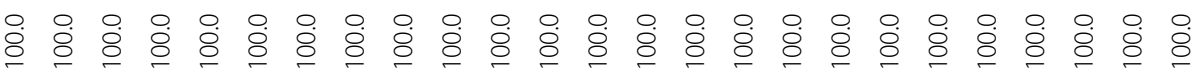

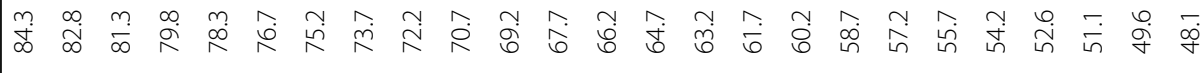

死

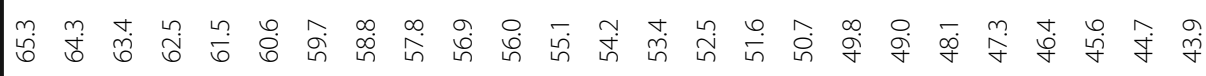

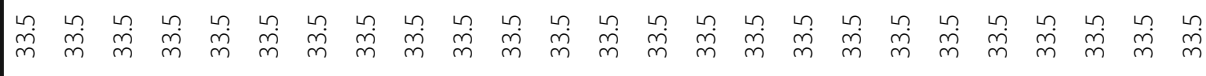

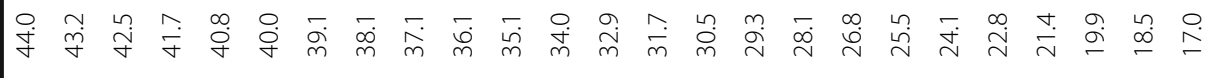

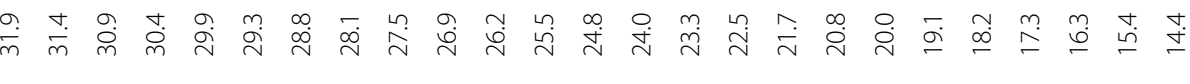

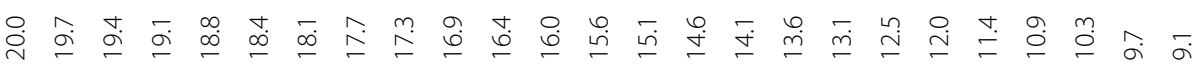

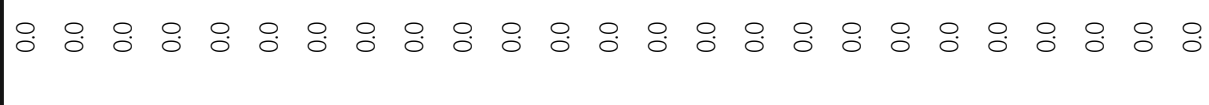

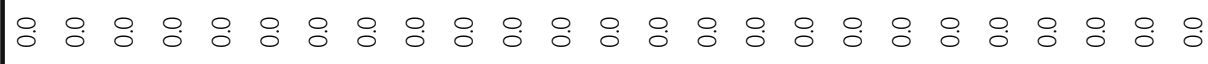




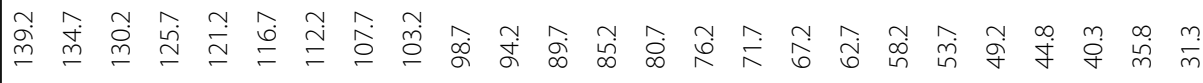

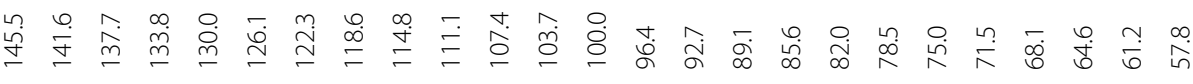

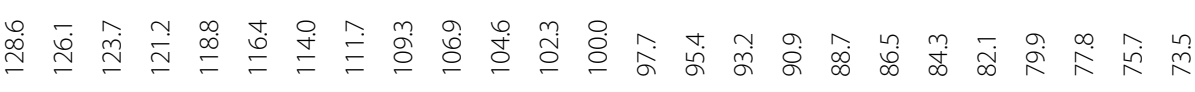

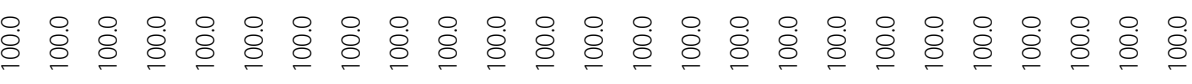

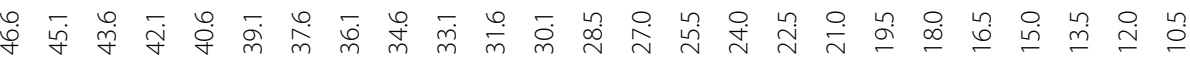

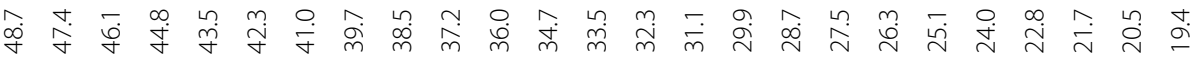

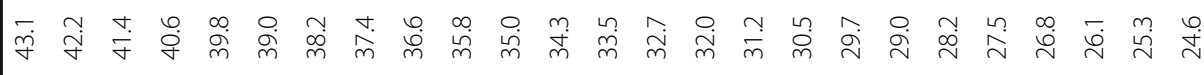

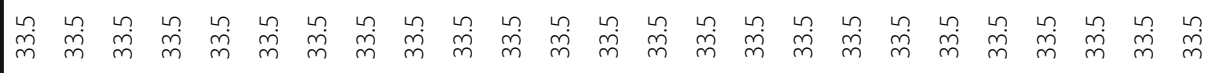

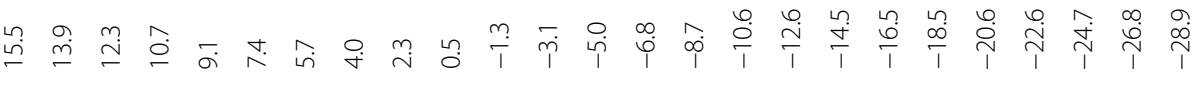

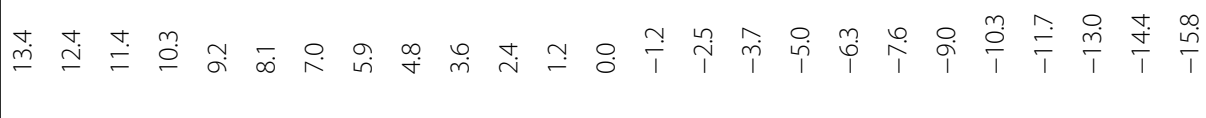

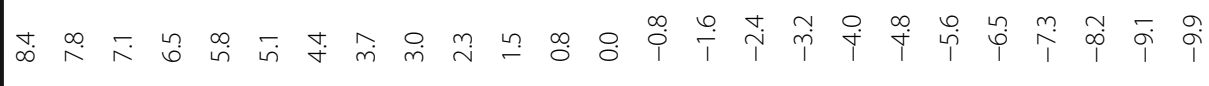

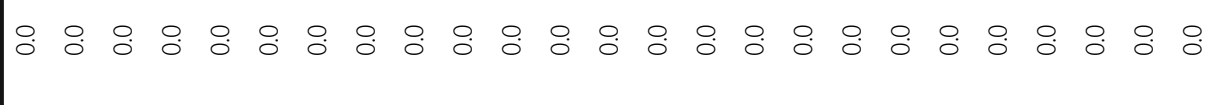

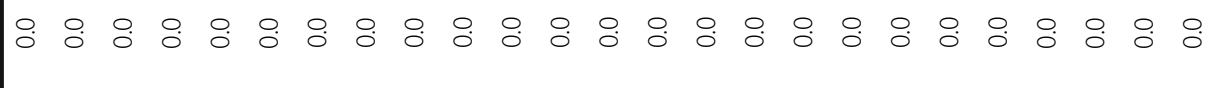

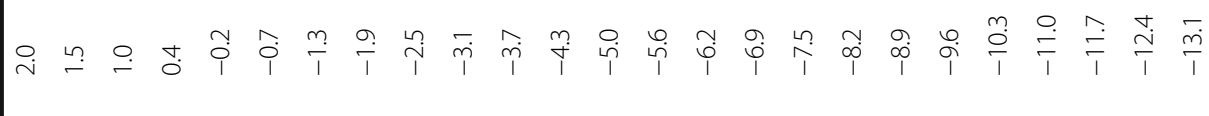

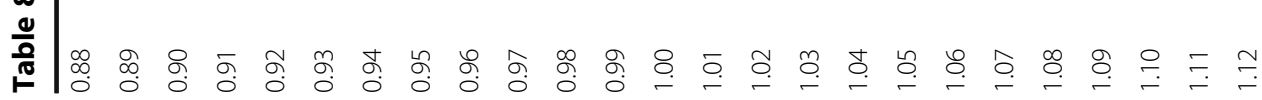




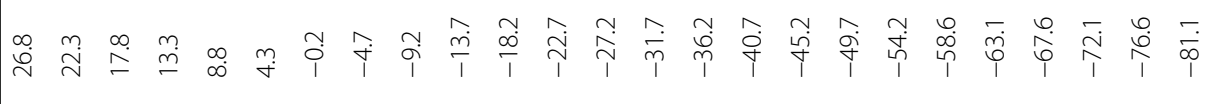

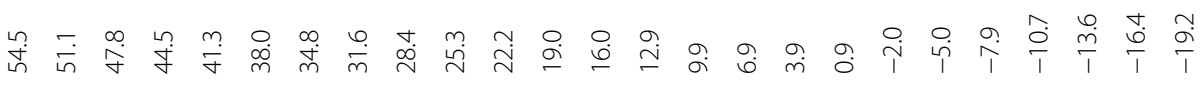

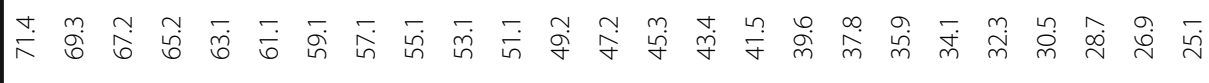

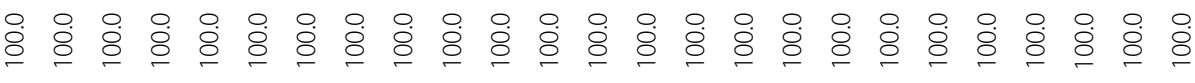

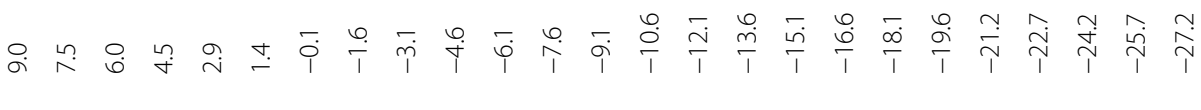

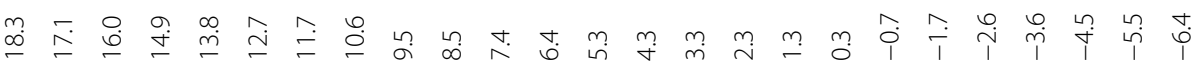

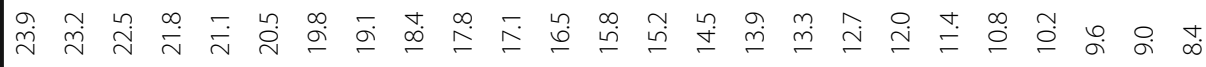

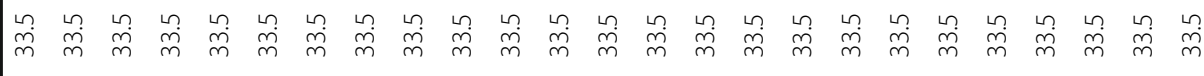

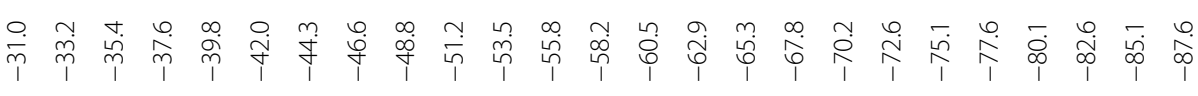

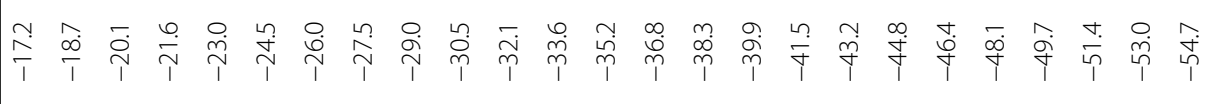

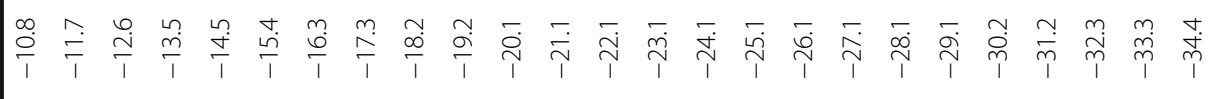

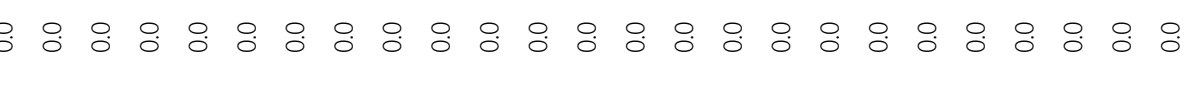

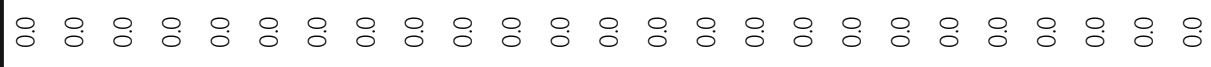

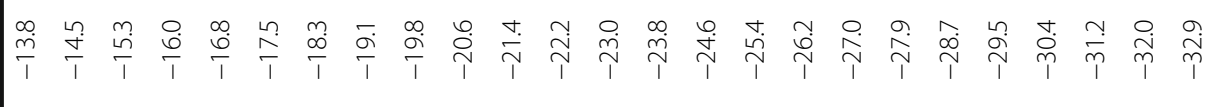




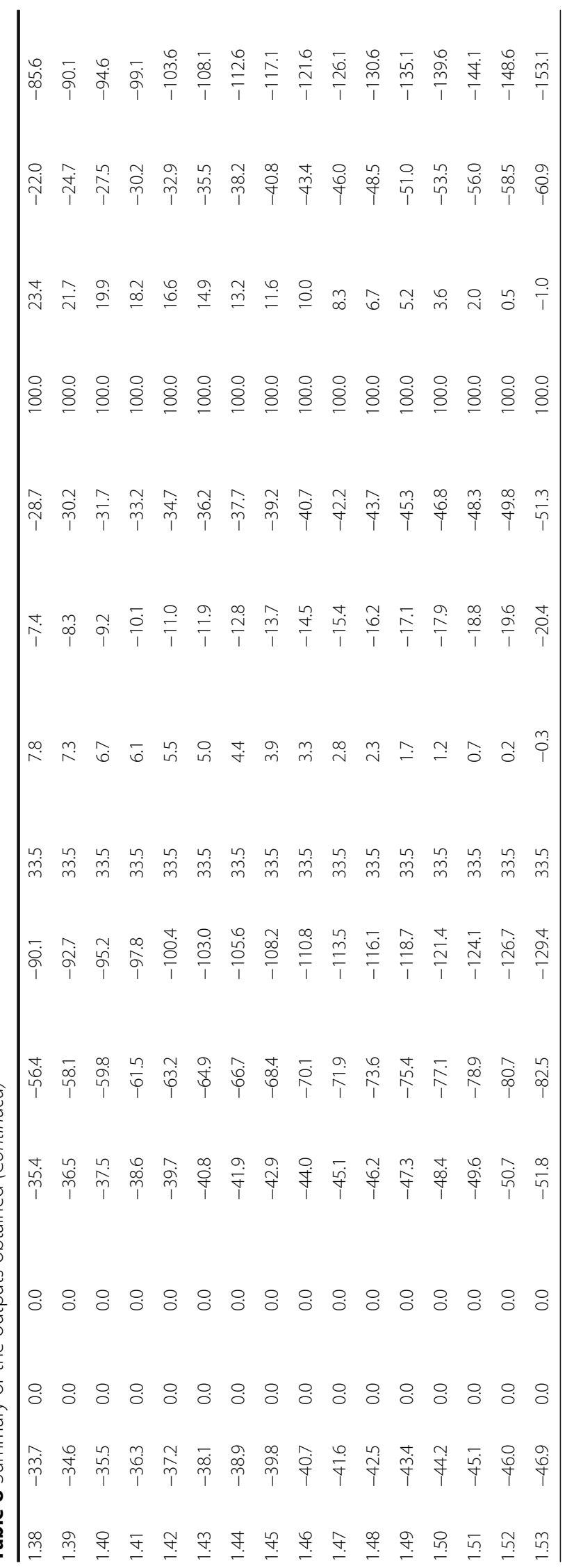




\section{Acknowledgements}

We would like to thank V. Ünal and A. Kamili for their explanations on how the remuneration systems work in Turkey and Morocco.

The authors also wish to thank two anonymous referees and the editor for all their positive comments. Any errors or views expressed in this paper are solely the responsibility of the authors.

\section{Authors' contributions}

All authors contributed to the paper. JG designed the study and the bio-economic model, contributed to the analysis and writing. JB, NC, KF and OG participated in the collection of remuneration systems information and made contributions to the analysis and the writing. CM and FM participated in the collection of remuneration systems information and made contributions to the bio-economic methodology, analysis and the writing. All authors read, edited and approved the final manuscript.

\section{Competing interests}

The authors declare that they have no competing interests.

\section{Author details}

${ }^{1}$ European Commission, Joint Research Centre, Directorate D - Sustainable Resources, Unit D.02 Water and Marine Resources, Via E. Fermi 2749, 21027 Ispra, Italy. ${ }^{2}$ Institut de Ciències del Mar - CSIC, Psg. Marítim de la Barceloneta 37-49, 08003 Barcelona, Spain. ${ }^{3}$ Université de Bretagne Occidentale, Ifremer, CNRS, UMR 6308, AMURE, IUEM, 12 rue du Kergoat, CS 93837, 29280 Brest, Cedex, France. ${ }^{4}$ Ifremer, Université de Bretagne Occidentale, CNRS, UMR 6308, AMURE, Unité d'Economie Maritime, IUEM, BP 70, F-29280 Brest, BP 70, France.

Received: 8 July 2016 Accepted: 3 January 2017

Published online: 15 February 2017

\section{References}

Abbott, Joshua K., Brian Garber-Yonts, and James E. Wilen. 2010. Employment and remuneration effects of IFQs in the Bering Sea/Aleutian Islands crab fisheries. Marine Resource Economics 25(4): 333-354.

Acheson, James M. 1981. Anthropology of fishing. Annual Review of Anthropology 10: 275-316.

Alemany, Francisco, and Federico Álvarez. 2003. Determination of effective effort on hake Merluccius merluccius in a Mediterranean trawl fishery. Scientia Marina 67(4): 491-499.

Alexander, T. 1973. American fishermen are missing the boat. Fortune 88(3): 190-97.

Alexander, Paul. 1977. Sea tenure in Sri Lanka. Ethnology 16: 231-251.

Allen, Franklin. 1985. On the fixed nature of sharecropping contracts. The Economic Journal 95: 30-48.

Anderson, Lee G. 1982. The share system in open-access and optimally regulated fisheries. Land Economics 58: 435-449. Astorkiza, Kepa, Ikerne del Valle, and Inmaculada Astorkiza. 1998. Fisheries policy and the Cofradias in the Basque country: the case of Albacore and Anchovy. Departamento de Economía: Universidad Pública de Navarra.

Azabou, Mongi, Lotfi Bouzaiane, and Jeffrey B. Nugent. 1989. Contractual choice in Tunisian fishing. In The new institutional economics and development, ed. Mustapha K. Nabli and Jeffrey B. Nugent, 158-177. Amsterdam: North-Holland.

Baddyr, Mohammed, and Sylvie Guénette. 2002. The fisheries off the atlantic coast of Morocco 1950-1997. In: Fisheries impacts on north atlantic ecosystems: catch, effort and national/regional data sets. Vancouver: University of British Columbia, Fisheries Centre Research Reports 9(3): 191-205.

Baisre Julio A. 2000. Crónica de la pesca marítima en Cuba (1935-1995): análisis de tendencias y del potencial pesquero. FAO, Documento Tecnico de Pesca (Vol. 394). FAO.

Bartelings, Heleen, Katell G. Hamon, Jorg Berkenhagen, and Erik F.C. Buisman. 2015. Bio-economic modelling for marine spatial planning application in North Sea shrimp and flatfish fisheries. Environmental Modelling \& Software 74: 156-172.

Bavinck, Maarten. 2001. Marine resource management: conflict and regulation in the fisheries of the Coromandel Coast. Delhi: Sage Publications.

Béné, Christophe. 1996. Effects of market constraints, the remuneration system, and resource dynamics on the spatial distribution of fishing effort. Canadian Journal of Fisheries and Aquatic Sciences 53(3): 563-571.

Beverton Raymond J.H., and Sidney J. Holt. 1957. On the dynamics of exploited fish populations. London: United Kingdom Ministry of Agriculture and Fisheries, Fishery Investigations, Series II, vol. XIX.

Boncoeur, Jean, Louisa Coglan, Betrand Le Gallic, and Sean Pascoe. 2000. On the (Ir)relevance of rates of return measures of economic performance to small boats. Fisheries Research 49: 105-115.

Breton, Yvan. 1973. A comparative study of work groups in an eastern Canadian peasant fishing community: bilateral kinship and adaptive processes. Ethnology 12: 393-418.

Christensen, James B. 1977. Motor power and women power: technological and economic change among Fanti fishermen in Ghana. pp. 71-95. In: Smith, Estellie M. 1980. Those Who Live From the Sea: A Study in Maritime Anthropology. American Ethnological Society Monographs. St. Paul: West Publishing Co. pp. 288.

Clark, Colin W. 1976. Mathematical bioeconomics: the optimal management of renewable resources. Inc: John Wiley \& Sons.

Colloca, Francesco, Crespi Valerio, Cerasi Sandro, and Salvatore R. Coppola. 2003. Artisanal fishery communities in the Mediterranean: two Case studies. In Evolution of the artisanal fishery in Cilento, Italy, COPEMED, FAO, 1-61.

Dichmont, Cathy M., Sean Pascoe, Tom Kompas, Andre E. Punt, and Roy A. Deng. 2010. On implementing maximum economic yield in commercial fisheries. Proceedings of the National Academy of Sciences 107: 16-21.

Eisenhardt, Kathleen. 1989. Agency theory: an assessment and review. Academy of Management Review 14(1): 57-74.

Failler, Pierre. 1996. Un Etat moderne signifie-t-il une pêche moderne? l'exemple de la Martinique, IIFET Conference Proceedings.

FAO (Food and Agriculture Organization of the United Nations). 2014a. The state of world fisheries and aquaculture 2014. Rome, Italy. 223 pp. 
George, Daniel, and Robert New. 2013. Australian fisheries surveys report 2012: financial and economic performance of the eastern tuna and billfish fishery, the commonwealth trawl sector and the gillnet, hook and trap sector. Canberra: Australian Bureau of Agricultural and Resource Economics and Sciences.

Giasson, Marie. 1981. Les rapports de production dans le secteur de la pêche à Conceicao da Barra (Brésil). Anthropologie et Societes 5(1): 117-134.

Gordon, H. Scott. 1953. An economic approach to the optimum utilization of fishery resources. Journal of the Fisheries Board of Canada 10(7): 442-457.

Gordon, H. Scott. 1954. The economic theory of a common property resource: the fishery. Journal of Political Economics 62: 124-142.

Green, Jerry R., and Nancy L. Stockey. 1983. A comparison of tournaments and contracts. Journal of Political Economy 91(3): 349-364.

Griffin, Wade L., Ronald D. Lacewell, and John P. Nichols. 1976. Optimum effort and rent distribution in the gulf of Mexico shrimp fishery. American Journal of Agricultural Economics 58: 644-652.

Guéguen, Frédéric. 2001. Notes sur la biologie de la crevette de profondeur Aristeus antillensis en Guyane française. Comptes Rendus de l'Académie des Sciences-Series III-Sciences de la Vie 324(8): 689-700.

Guillen, Jordi, Claire Macher, Mathieu Merzéréaud, Michel Bertignac, Spyros Fifas, and Olivier Guyader. 2013. Estimating MSY and MEY in multi-species and multi-fleet fisheries, consequences and limits: an application to the Bay of Biscay mixed fishery. Marine Policy 40: 64-74.

Guillen, Jordi, Claire Macher, Jean Boncoeur, Mathieu Merzéréaud, and Olivier Guyader. 2015. Effects of the share remuneration system on fisheries management targets and rent distribution. Marine Resource Economics 30(2): 123-138.

Guyader, Olivier, and Olivier Thebaud. 2001. Distributional issues in the operation of rights-based fisheries management systems. Marine Policy 25: 103-112.

Guyader, Olivier, Manuel Bellanger, Lionel Reynal, Sébastien Demanèche, and Patrick Berthou. 2013. Fishing strategies, economic performance and management of moored fishing aggregating devices in Guadeloupe. Aquatic Living Resources 26(1): 97-105.

Hall, Stephen J., Ray Hilborn, Neil L. Andrew, and Edward H. Allison. 2013. Innovations in capture fisheries are an imperative for nutrition security in the developing world. Proceedings of the National Academy of Sciences 110(21): 8393-8398.

Hämäläinen, Raimo P., Jukka Ruusunen, and Veijo Kaitala. 1990. Cartels and dynamic contracts in share fishing. Journal of Environmental Economics and Management 19: 175-192.

Hannesson, Rognvaldur. 2007. Taxes, ITQs, investments, and revenue sharing. Marine Resource Economics 22: 363-371.

Hannesson, Rognvaldur. 1993. Bioeconomic analysis of fisheries. Oxford: Fishing News Books Ltd.

Hatcher, Aaron. 2010. Fishery share systems and ITQ markets: who should pay for quota? CEMARE Research paper no. 167.

McCall Howard, Penny. 2012. Sharing or appropriation? Share systems, class and commodity relations in Scottish fisheries. Journal of Agrarian Change 12(2-3): 316-343.

Huntsman, Archibald G. 1951. Research on use and increase of fish stocks. Proceedings of the United Nations scientific conference on the conservation and utilization of resources. 1949. Lake Success, 7, United Nations, New York, pp. 169-171.

ICES (International Council for the Exploration of the Sea). 2010. Report of the workshop on implementing the ICES Fmsy framework. ICES CM 2010/ACOM:54, 22-26 March 2010, Copenhagen, Denmark; 83 pp.

ILO (International Labour Organization). 2004. Conditions of work in the fishing sector A comprehensive standard (a Convention supplemented by a Recommendation) on work in the fishing sector. International Labour Conference, 92nd Session, Report V (1). International Labour Office Geneva.

ILO (International Labour Organization). 2013. Employment practices and working conditions in Thailand's fishing sector. Bangkok. 105 pp.

Jin, Di, Eric Thunberg, Hauke Kite-Powell, and Kevin Blake. 2002. Total factor productivity change in the New England groundfish fishery: 1964-1993. Journal of Environmental Economics and Management 44: 540-556.

Johnson, D. Gale. 1950. Resource allocation under share contracts. Journal of Political Economy 58(2): 111-123.

Jorion, Paul. 1979. Les deux concepts fondamentaux de la pêche artisanale La «saison» et le «métier» à Houat (Morbihan). Ethnologie Française 9(2): 135-146.

Kamili, Abdelkabir. 2006. Bio-économie et gestion de la pêcherie des petits pélagiques - cas de l'Atlantique Centre Marocain. Master Tesis. University of Barcelona.

Kessler, lan. 2009. Remuneration systems. In: Managing Human Resources: Personnel Management in Transition. Oxford: Blackwell Publishing. pp. 317-345.

Kompas, Tom. 2005. Fisheries management: economic efficiency and the concept of 'Maximum Economic Yield'. Australian Commodities 12: 152-160.

Lazear, Edward P. 1986. Salaries and piece rates. The Journal of Business 59(3): 405-431.

Lazear, Edward P., and Sherwin Rosen. 1981. Rank-order tournaments as optimum labor contracts. Journal of Political Economy 89: 841-864.

Lleonart, Jordi, Francesc Maynou, and Ramon Franquesa. 1999. A bioeconomic model for Mediterranean fisheries. Fisheries Economics Newsletter 48: 1-16.

Lleonart, Jordi, Francesc Maynou, Laura Recasens, and Ramon Franquesa. 2003. A bioeconomic model for Mediterranean fisheries, the hake off Catalonia (western Mediterranean) as a case study. Scientia Marina 67(1): 337-351.

Lofgren, Orvar. 1972. Resource management and family firms: Swedish West Coast fishermen. In: Andersen, Raoul, and Cato Wadel. 1972. North Atlantic fishermen: anthropological essays on modern fishing. No. 5. Institute of Social and Economic Research, Memorial University of New found land. pp. 82-103.

Macher, Claire, Olivier Guyader, Catherine Talidec, and Michel Bertignac. 2008. Cost-benefit analysis of improving trawl selectivity in the case of discards: the nephrops norvegicus fishery in the Bay of Biscay. Fisheries Research 92: 76-89.

Malouli Idrissi, Mohammed, Zahri Yassine, Houssa Rachida, Abdellaoui Benyounes, and Ouamari Najib El. 2003. Artisanal fishery communities in the Mediterranean: two Case studies. In Pêche artisanale dans la lagune de Nador, Maroc: exploitation et aspects socio-économiques, COPEMED, FAO, 112th ed, 62-104. 
Mardle, Simon, Sean Pascoe, Jean Boncoeur, Bertrand Le Gallic, Juan J. Garcia-Hoyo, Ines Herrero, Ramon JimenezToribio, Concepcion Cortes, Nuria Padilla, Jesper Raakjaer Nielsen, and Christoph Mathiesen. 2002. Objectives of fisheries management: case studies from the UK, France, Spain and Denmark. Marine Policy 26: 415-428.

Marion, Del Sol, Annie Gouzien, Nadine Souchard, and Pascale Turquet. 1998. Répartition du travail et identités salariales. Travail et emploi 63: 74-77.

Matthiasson, Thorolfur. 1997. Fixed wage or share: contingent contract renewal and skipper motivation. Mimeo, Institute for Economic Studies, University of Iceland.

Maynou, Francesc, Francesc Sardà, Sergi Tudela, and Montserrat Demestre. 2006. Management strategies for red shrimp (Aristeus antennatus) fisheries in the Catalan Sea (NW Mediterranean) based on bioeconomic simulation analysis. Aquatic Living Resources 19(2): 161-171.

McClanahan, Tim, Edward H. Allison, and Joshua E. Cinner. 2013. Managing fisheries for human and food security. Fish and Fisheries 16(1): 78-103.

McConnell, Kenneth E., and Michael Price. 2006. The lay system in commercial fisheries: origin and implications. Journal of Environmental Economics and Management 51(3): 295-307.

McGoodwin, James R. 1976. Society, economy, and shark-fishing crews in rural northwest Mexico. Ethnology 15(4): $377-391$.

McGoodwin, James R. 1991. Crisis in the world's fisheries: people, problems, and policies. Stanford: Stanford University Press.

Middleton, DeWight R. 1977. Changing economics in an Ecuadorian maritime community. pp. 111-124. In: Smith, Estellie M. 1980. Those Who Live From the Sea: A Study in Maritime Anthropology. American Ethnological Society Monographs. West Publishing Co. pp. 288.

Newbery, David M.G. 1977. Risk sharing, sharecropping and uncertain labour markets. Review of Economic Studies 44(3): 585-594. Nguyen, Quang, and PingSun Leung. 2009. Choice of Remuneration Regime in Fisheries: The Case of Hawaii's Longline Fisheries. Journal of Agricultural and Resource Economics 34(3): 498-517.

OECD (Organisation for Economic Co-operation and Development). 1998. Review of Fisheries in OECD Countries: Glossary. Available at: http://stats.oecd.org/glossary/detail.asp?ID=994.

OECD (Organisation for Economic Co-operation and Development). 2012. Rebuilding Fisheries: The Way Forward. OECD Publishing. Available at: http://www.oecd.org/tad/fisheries/rebuildingfisheriesthewayforward.htm.

Pascual Fernandez, José. 1999. The share system in fishing: the case of Canary Islands. Europaea 5(2): 65-87.

Pilling, Graham M., Laurence T. Kell, Trevor Hutton, Peter J. Bromley, Alex N. Tidd, and Loes J. Bolle. 2008. Can economic and biological management objectives be achieved by the use of MSY-based reference points? A North Sea plaice (Pleuronectes platessa) and sole (Solea solea) case study. ICES Journal of Marine Science 65: 1069-1080.

Platteau, Jean Philippe, and Jeffrey Nugent. 1992. Share contracts and their rationale: lessons from marine fishing. Journal of Development Studies 28: 386-422.

Plourde, Charles, and J. Barry Smith. 1989. Crop sharing in the fishery and industry equilibrium. Marine Resource Economics 6: 179-193.

Prellezo, Raúl, and Ane Iriondo. 2016. Measuring the economic efficiency of a crew share remuneration system: a case study of the Basque purse seiner-live bait fleet. Aquatic Living Resources 29(1): 106.

Prins Adriaan Hendrik, Johan. 1965. Sailing from Lamu: a study of maritime culture in Islamic East Africa. Assen: Van Gorcum.

Ray, Hilborn. 2007. Defining success in fisheries and conflicts in objectives. Marine Policy 31: 153-158.

Ray, Hilborn, and Kevin Stokes. 2010. Defining overfished stocks: have we lost the plot? Fisheries 35: 113-20.

Reglero, Patricia, and Beatriz Morales-Nin. 2008. Relationship between first sale price, body size and total catch of trammelnet target species in Majorca (NW Mediterranean). Fisheries Research 92(1): 102-106.

Reid, Joseph D. 1976. Sharecropping and agricultural uncertainty. Economic Development and Cultural Change 24(3): 549-576.

Salazar Espinoza, C. 2015. Share contract choices and economic performance: empirical evidence from the artisanal fisheries sector in Chile. Marine Resource Economics 30(1): 71-95.

Samy-Kamal, Mohamed, Aitor Forcada, and José Luis Sánchez-Lizaso. 2014. Trawling fishery of the western Mediterranean Sea: métiers identification, effort characteristics, landings and income profiles. Ocean \& Coastal Management 102(26): 269-284.

Schaefer, Milner B. 1954. Some aspects of the dynamics of populations important to the management of the commercial marine fisheries. Inter-American Tropical Tuna Commission Bulletin 1(2): 23-56.

Schaefer, Milner B. 1957. Some considerations of population dynamics and economics in relation to the management of the commercial marine fisheries. Journal of the Fisheries Board of Canada 14(5): 669-681.

Schaefer, Milner B. 1970. Men, birds and anchovies in the Peru current-dynamic interactions. Transactions of the American Fisheries Society 99(3): 461-467.

Schloss, David F. 1898. Methods of industrial remuneration, 446. England: Williams and Norgate.

Skirtun, Maggie, Mary Stephan, and Kasia Mazur. 2014. Australian fisheries economic indicators report 2013: financial and economic performance of the northern prawn fishery. Canberra: ABARES.

Smith, Ian R., Daniel Pauly, and Antonio N. Mines. 1983. Small-scale fisheries of San Miguel Bay: Philippines: options for management and research. ICLARM Technical Report 11: 80.

Squires, Dale, James Kirkley, and Clement A. Tisdell. 1995. Individual transferable quota as a management tool. Reviews in Fisheries Science 3: 141-169.

STECF (Scientific, Technical and Economic Committee for Fisheries). 2012 Annual Economic Report on the EU fishing fleet (STECF-12-10). Publications Office of the European Union Luxembourg. 380 pp.

Stiglitz, Joseph E. 1974. Incentives and risk sharing in sharecropping. Review of Economic Studies 41(2): 219-256.

Sutinen, Jon G. 1979. Fishermens' remuneration systems and implications for fisheries development. Scottish Journal of Political Economy 26: 147-162.

Thuy, Pham Thi Thanh, Flaaten Ola, and Anh Nguyen Thi Kim. 2013. Remuneration systems and economic performance: theory and Vietnamese small-scale purse seine fisheries. Marine Resource Economics 28(1): 19-41.

Tietze Uwe, Joel Prado, Jean-Michel Le Ry, and Rolf Lasch. 2001. Techno-economic performance of marine capture fisheries, FAO technical paper No 421, Rome, FAO, 79 pp. 
Ünal, Vahdet. 2002. Trol Balıkçılığında Gelir Dağılımı ve Sürdürülebilirlilik Açııından Değerlendirilmesi (Income distribution and sustainability evaluation of trawl fisheries). In: Özhan, Erdal, and Necdet Alpaslan. (Editors). Türkiye'nin Kıyı ve Deniz Alanları IV (Turkey's coastal and marine areas). Proceedings of the National Conference on Coastal Zone Management. 5-8 November 2002. (in Turkish).

Verhulst, Pierre-François. 1838. Notice sur la loi que la population suit dans son accroissement. Correspondance mathématique et physique publiée par a. Quetelet 10: 113-121.

Vestergaard, Niels. 2010. Principal-Agent problems in fisheries. In: Handbook of Marine Fisheries Conservation and Management. New York: Oxford University Press.

Wadel, Cato. 1972. Capitalization and ownership: the persistence of fishermen-ownership in the Norwegian herring fishery. In: Andersen, Raoul, and Cato Wadel. 1972. North Atlantic fishermen: anthropological essays on modern fishing. No. 5. Institute of Social and Economic Research, Memorial University of Newfoundland.

Weitzman, Martin, and Douglas Kruse. 1990. Profit sharing and productivity. In Paying for productivity: a look at the evidence, ed. Alan S. Blinder, 95-140. Washington: Brookings Institution.

Willmann Rolf, Kieran Kelleher, and Ragnar Arnason. 2008. The Sunken Billions: The Economic Justification for Fisheries Reform. Joint publication of the World Bank and the FAO. ISBN 978-0-8213-7790-1. $100 \mathrm{pp}$.

Worm, Boris, Ray Hilborn, Julia K. Baum, Trevor A. Branch, Jeremy S. Collie, Christopher Costello, Michael J. Fogarty, Elizabeth A. Fulton, Jeffrey A. Hutchings, Simon Jennings, Olaf P. Jensen, Heike K. Lotze, Pamela M. Mace, Tim R. McClanahan, Coilin Minto, Stephen R. Palumbi, Ana M. Parma, Daniel Ricard, Andrew A. Rosenberg, Reg Watson, and Dirk Zeller. 2009. Rebuilding global fisheries. Science 325: 578-585.

Zoeteweij, Herbert. 1956. Fishermen's remuneration. In The economics of fisheries, ed. Ralph Turvey and Jack Wiseman. Rome: FAO.

Submit your manuscript to a SpringerOpen ${ }^{\circ}$ journal and benefit from:

- Convenient online submission

- Rigorous peer review

- Immediate publication on acceptance

- Open access: articles freely available online

- High visibility within the field

- Retaining the copyright to your article

Submit your next manuscript at $\boldsymbol{\nabla}$ springeropen.com 